\title{
Spatial variability of Chondrichthyes in the northern Mediterranean
}

\author{
Maria C. Follesa ${ }^{1}$, Martina F. Marongiu ${ }^{1}$, Walter Zupa ${ }^{2}$, Andrea Bellodi ${ }^{1}$, Alessandro Cau ${ }^{1}$, \\ Rita Cannas ${ }^{1}$, Francesco Colloca ${ }^{3}$, Mirko Djurovic ${ }^{4}$, Igor Isajlovic ${ }^{5}$, Angélique Jadaud ${ }^{6}$, \\ Chiara Manfredi ${ }^{7}$, Antonello Mulas ${ }^{1}$, Panagiota Peristeraki ${ }^{8,9}$, Cristina Porcu ${ }^{1}$, Sergio \\ Ramirez-Amaro ${ }^{10}$, Francisca Salmerón Jiménez ${ }^{11}$, Fabrizio Serena ${ }^{12}$, Letizia Sion ${ }^{13}$, Ioannis \\ Thasitis ${ }^{14}$, Angelo Cau ${ }^{1}$, Pierluigi Carbonara ${ }^{2}$ \\ ${ }^{1}$ Department of Life and Environmental Science, University of Cagliari, Via T. Fiorelli 1, Cagliari, Italy. \\ (MCF) (Corresponding author). E-mail: follesac@ unica.it. ORCID iD: https://orcid.org/0000-0001-8320-9974 \\ (MFM) E-mail: mfmarongiu @ unica.it. ORCID iD: https://orcid.org/0000-0002-0582-8865 \\ (AB) E-mail: abellodi@unica.it. ORCID iD: https://orcid.org/0000-0002-9017-1692 \\ (AlC) E-mail: alessandrocau@ @unica.it. ORCID iD: https://orcid.org/0000-0003-4082-7531 \\ (RC) E-mail: rcannas@ unica.it. ORCID iD: https://orcid.org/0000-0001-6627-4053 \\ (AM) E-mail: amulas @ unica.it. ORCID iD: https://orcid.org/0000-0003-1635-691X \\ (CP) E-mail: cporcu@unica.it. ORCID iD: https://orcid.org/0000-0003-2649-6502 \\ (AnC) E-mail: cau@unica.it. ORCID iD: https://orcid.org/0000-0002-6897-2127 \\ ${ }^{2}$ COISPA Tecnologia \& Ricerca, Via dei Trulli 18-20, Bari, Italy. \\ (WZ) E-mail: zupa@ coispa.it. ORCID iD: https://orcid.org/0000-0002-2058-8652 \\ (PC) E-mail: carbonara@ coispa.it. ORCID iD: https://orcid.org/0000-0002-2529-2535 \\ ${ }^{3}$ Stazione Zoologica A. Dohrn, Villa comunale, Napoli, Italy. \\ (FC) E-mail: francesco.colloca@iamc.cnr.it. ORCID iD: https://orcid.org/0000-0002-0574-2893 \\ ${ }_{4}^{4}$ Institute of Marine Biology, University of Montenegro, PBox 69, 85330 Kotor, Montenegro. \\ (MD) E-mail: mirko.djur@ac.me. ORCID iD: https://orcid.org/0000-0002-4352-9911 \\ ${ }^{5}$ Institute of Oceanography and Fisheries, Set. I Mestrovica 63, 21000 Split, Croatia. \\ (II) E-mail: igor@izor.hr. ORCID iD: https://orcid.org/0000-0001-7101-9575 \\ ${ }^{6}$ MARBEC-IFREMER, IRD, Université Montpellier 2, CNRS, Avenue Jean Monnet, CS 30171, 34203 Sète Cedex, \\ France. \\ (AJ) E-mail: angelique.jadaud@ifremer.fr. ORCID iD: https://orcid.org/0000-0001-6858-3570 \\ ${ }^{7}$ Laboratorio di Biologia Marina e Pesca di Fano, Università di Bologna, viale Adriatico 1/n, 61311 Fano, Italy. \\ (CM) E-mail: chiara.manfredi3@unibo.it. ORCID iD: https://orcid.org/0000-0002-2852-4856 \\ ${ }^{8}$ Hellenic Center for Marine Research, Institute of Marine Biological Resources and Inland Waters, 71003, Heraklion, \\ Greece. \\ (PP) E-mail: notap @ hcmr.gr. ORCID iD: https://orcid.org/0000-0002-8608-078X \\ ${ }^{9}$ University of Crete, Biology Department, Stavrakia, Heraklion, Crete. \\ ${ }^{10}$ Instituto Español de Oceanografía, Centro Oceanográfico de Baleares, Moll de Ponent s/n, 07015 Palma, Spain. \\ (SR-A) E-mail: sergio.ramirez@ba.ieo.es. ORCID iD: https://orcid.org/0000-0002-0298-0749 \\ ${ }^{11}$ Instituto Español de Oceanografía, Centro Oceanográfico de Málaga, Puerto Pesquero s/n, 29640 Fuengirola, Spain. \\ (FSJ) E-mail: paqui.salmeron@ieo.es.ORCID iD: https://orcid.org/0000-0001-8907-5444 \\ ${ }^{12}$ National Research Council, Institute for Coastal Marine Environment, Via Vaccara 61, 91026 Mazara del Vallo, TP Italy. \\ (FS) E-mail: fabrizio.serena@ irbim.cnr.it. ORCID iD: https://orcid.org/0000-0003-1428-8124 \\ ${ }^{13}$ Department of Biology, University of Bari Aldo Moro, Via Orabona 4, 70125 Bari, Italy. \\ (LS) E-mail: letizia.sion@ uniba.it. ORCID iD: https://orcid.org/0000-0002-0308-1841 \\ ${ }^{14}$ Department of Fisheries and Marine Research, 101 Vithleem str., 1416 Nicosia, Cyprus. \\ (IT) E-mail: ithasitis@dfmr.moa.gov.cy. ORCID iD: https://orcid.org/0000-0002-0940-2212
}


pressure, such as southwestern Sicily, show a high abundance, suggesting that other environmental drivers work together with fishing pressure to shape their distribution. Results of generalized additive models highlighted that depth is one of the most important environmental drivers influencing the distribution of both batoid and shark species, although temperature also showed a significant influence on their distribution. The approach explored in this work shows the possibility of producing maps modelling the distribution of demersal chondrichthyans in the Mediterranean that are useful for the management and conservation of these species at a regional scale. However, because of the vulnerability of these species to fishing exploitation, fishing pressure should be further incorporated in these models in addition to these environmental drivers.

Keywords: fish; Chondrichthyes; bottom trawl surveys; distribution; abundance; Mediterranean.

\section{Variabilidad espacial de Chondrichthyes en el norte del Mediterráneo}

Resumen: Gracias a la disponibilidad de los datos de campañas de pesca experimental MEDITS, se ha realizado una imagen estandarizada de la presencia y abundancia de Chondrichthyes demersales en el norte del Mediterráneo. Durante el período primavera-verano entre 2012 y 2015, se detectaron 41 Chondrichthyes, incluidos 18 tiburones (5 órdenes y 11 familias), 22 batoides (3 órdenes y 4 familias) y 1 quimera, de varias Subáreas Geográficas (GSA) establecidas por la Comisión General de Pesca para el Mediterráneo en la zona. Los batoides tuvieron una distribución preferencial en la plataforma continental (10-200 m de profundidad), mientras que las especies de tiburones fueron más frecuentes en la ladera (200-800 m de profundidad). Solo tres especies, Carcharhiniformes Galeus melastomus, Scyliorhinus canicula y Torpediniformes Torpedo marmorata fueron capturadas en todos los GSA estudiados. En la plataforma continental, la familia Rajidae fue la más abundante, representada en primer lugar por Raja clavata y luego por R. miraletus, R. polystigma y R. asterias. La pendiente se caracterizó por la prevalencia de G. melastomus en todos los GSA, seguido de S. canicula, E. spinax y Squalus blainville. Las áreas bajo mayor presión de pesca, como el Mar Adriático y la costa española (con la excepción de las Islas Baleares), registran una baja abundancia de condricthianos, pero otras áreas con un alto nivel de presión de pesca, como el suroeste de Sicilia, presentan una gran abundancia de estas especies. Sugiere que otros impulsores ambientales trabajen juntos con la presión pesquera para dar forma a su distribución. Los resultados de los modelos aditivos generalizados resaltaron que la profundidad es uno de los factores ambientales más importantes que influyen en la distribución de las especies de batoides y tiburones, aunque la temperatura también mostró una influencia significativa en su distribución. El enfoque explorado en este trabajo muestra la posibilidad de producir mapas que modelen la distribución de los condrictios demersales en el Mediterráneo, útiles para el manejo y la conservación de estas especies a escala regional. Sin embargo, teniendo en cuenta la vulnerabilidad de estas especies a la explotación pesquera, la presión pesquera debería incorporarse a estos modelos, además de estos factores ambientales.

Palabras clave: Chondrichthyes; campañas de pesca experimental de arrastre; distribución; abundancia; mar Mediterráneo.

Citation/Cómo citar este artículo: Follesa M.C., Marongiu M.F., Zupa W., Bellodi A., Cau A., Cannas R., Colloca F., Djurovic M., Isajlovic I., Jadaud A., Manfredi C., Mulas A., Peristeraki P., Porcu C., Ramirez-Amaro S., Salmerón Jiménez F., Serena F., Sion L., Thasitis I., Cau A., Carbonara P. 2019. Spatial variability of Chondrichthyes in the northern Mediterranean. Sci. Mar. 83S1: 81-100. https://doi.org/10.3989/scimar.04998.23A

Editor: E. Massutí.

Received: March 15, 2018. Accepted: September 12, 2019. Published: November 15. 2019.

Copyright: ( 2019 CSIC. This is an open-access article distributed under the terms of the Creative Commons Attribution 4.0 International (CC BY 4.0) License.

\section{INTRODUCTION}

Chondrichthyes are one of the oldest and most ecologically diverse vertebrate lineages. They appeared about 420 million years ago occupying the upper levels of aquatic food webs (Compagno 1990, Kriwet et al. 2008). Today, they have a conspicuous number of predators playing an important role within the marine ecosystem (Stevens et al. 2000, Ferretti et al. 2010, Heithaus et al. 2012), so if these species disappear, the balance within the aquatic food webs would be compromised. It is well known that overfishing and habitat degradation have altered marine animal populations (Polidoro et al. 2012), especially those of sharks and rays (Ferretti et al. 2010, Dulvy et al. 2014). Cartilaginous fish are intrinsically sensitive to high fishing mortality because of their K-selected strategy (e.g. slow growth, late attainment of sexual maturity, long life spans and low fecundity; Stevens et al. 2000). They are frequently captured incidentally, but are often retained as valuable by-catch of fisheries that focus on more productive teleost fish species (Stevens et al. 2005). At present, fishing pressure on chondrichthyan species is increasing because of the high, and in some cases rising, value of their meat, fins, livers, and/or gill rakers (Fowler et al. 2002, Clarke et al. 2006, Lack and Sant 2009). The landings of sharks and rays reported to the Food and Agriculture Organization of the United Nations increased to a peak in 2003 and declined by $20 \%$ afterwards (FAO 2010, Frodella et al. 2016). However, recent global data show an increase of $42 \%$ of the trade in shark meat (Dent and Clarke 2015) and the true total catch is considered to be about $3 / 4$ times greater than reported (Clarke et al. 2006, Worm et al. 2013). Most chondrichthyan catches are unregulated and often misidentified, unrecorded, aggregated or discarded at sea, resulting in a lack of species-specific landings information (Iglésias et al. 2010, Bornatowski et al. 2013, Cariani et al. 2017).

Humans have been exploiting marine resources, including sharks, along the Mediterranean coasts since ancient times (Farrugio et al. 1993). An analysis of threat levels across all chondrichthyan species has revealed the Mediterranean as a key hotspot of extinction risk (Dulvy et al. 2014). According to the recent assessment of the International Union for the Conservation of the Nature (IUCN), 50\% of rays (16 of 32 species) and $54 \%$ of sharks (22 of 41 species) in the Mediterranean are facing a high risk of extinction, whereas the only chimaera species (Chimaera monstrosa) is 
Table 1. - Number of MEDITS hauls carried out annually during the period 2012-2015 and analysed in the present study by geographical sub-area (GSA) of the General Fisheries Commission for the Mediterranean, country and depth strata (total, 10-800 m; continental shelf, 10-200 m; slope, 201-800 m).

\begin{tabular}{|c|c|c|c|c|c|}
\hline GSA & Country & Area & Total hauls & Shelf hauls & Slope hauls \\
\hline 1 & Spain & Northern Alboran & 187 & 71 & 116 \\
\hline 5 & Spain & Balearic Islands & 218 & 142 & 76 \\
\hline 6 & Spain & Northern Spain & 388 & 282 & 106 \\
\hline 7 & France & Gulf of Lions & 66 & 55 & 11 \\
\hline 8 & France & Corsica & 23 & 10 & 13 \\
\hline 9 & Italy & Ligurian, northern and central Tyrrhenian seas & 120 & 55 & 65 \\
\hline 10 & Italy & Central and southern Tyrrhenian seas & 70 & 29 & 41 \\
\hline 11 & Italy & Sardinian seas & 101 & 63 & 38 \\
\hline 16 & Italy & Strait of Sicily & 120 & 55 & 65 \\
\hline 17 & Italy, Slovenia, Croatia & Northern Adriatic & 182 & 169 & 13 \\
\hline 18 & Italy, Albania, Montenegro & Southern Adriatic & 90 & 63 & 27 \\
\hline 19 & Italy & Northwestern Ionian & 70 & 27 & 43 \\
\hline 20 & Greece & Eastern Ionian Sea & 50 & 24 & 26 \\
\hline 22 & Greece & Argosaronikos, northern and southern Aegean & 123 & 63 & 60 \\
\hline 23 & Greece & Cretan Sea & 21 & 14 & 7 \\
\hline 25 & Cyprus & Cyprus & 26 & 19 & 7 \\
\hline
\end{tabular}

considered as least concern (Dulvy et al. 2016). As highlighted above, the principal driver of decline and local extinction is overfishing. Most species are taken as retained valuable by-catch in the bottom trawl and the small-scale multispecies fisheries. However, bycatch volumes and species composition of chondrichthyans are poorly documented in the Mediterranean and data are rarely incorporated into national and international statistics. Therefore, sharks and rays caught as by-catch can be only delivered as an approximation (Camhi et al. 1998, GFCM 2014). Moreover, despite being banned in 2002, illegal driftnetting is widespread throughout the basin: fleets from Algeria, Italy, Morocco, Turkey, among others, continue to fish illegally with pelagic driftnets (Notarbartolo Di Sciara 2014), and this represents an important and largely hidden source of mortality for pelagic sharks. More recently, a significant decline in chondrichthyan species richness has been reported throughout the Mediterranean, due to increasing threats and local extinctions (Nieto et al. 2015, Davidson et al. 2016, Dulvy et al. 2016).
Starting from 2010, the General Fisheries Commission for the Mediterranean (GFCM) has adopted measures to reduce the by-catch of pelagic sharks, has banned finning practices and has also prohibited the capture and sale of the sharks and rays species listed in Annex II of the Protocol of the Barcelona Convention (FAO 2016). However, no effective management measures against the overexploitation of many commercial species have been successfully implemented or enforced (Vasilakopoulos et al. 2014, Osio et al. 2015). In addition, data on the stock status of sharks and rays remain poor or non-existent (Polidoro et al. 2008, Worm et al. 2013, Colloca et al. 2017).

Numerous studies on chondrichthyan species were made during the first decade of the $21^{\text {st }}$ century in the western (e.g. Carbonell et al. 2003, Moranta et al. 2008a, b), central (e.g. Sion et al. 2004, Abella and Serena 2005, Ferretti et al. 2005) and eastern Mediterranean (e.g. Megalofonou et al. 2005, Tserpes et al. 2006, Peristeraki et al. 2008). However, only a few of them have been updated, mainly those related to Span-

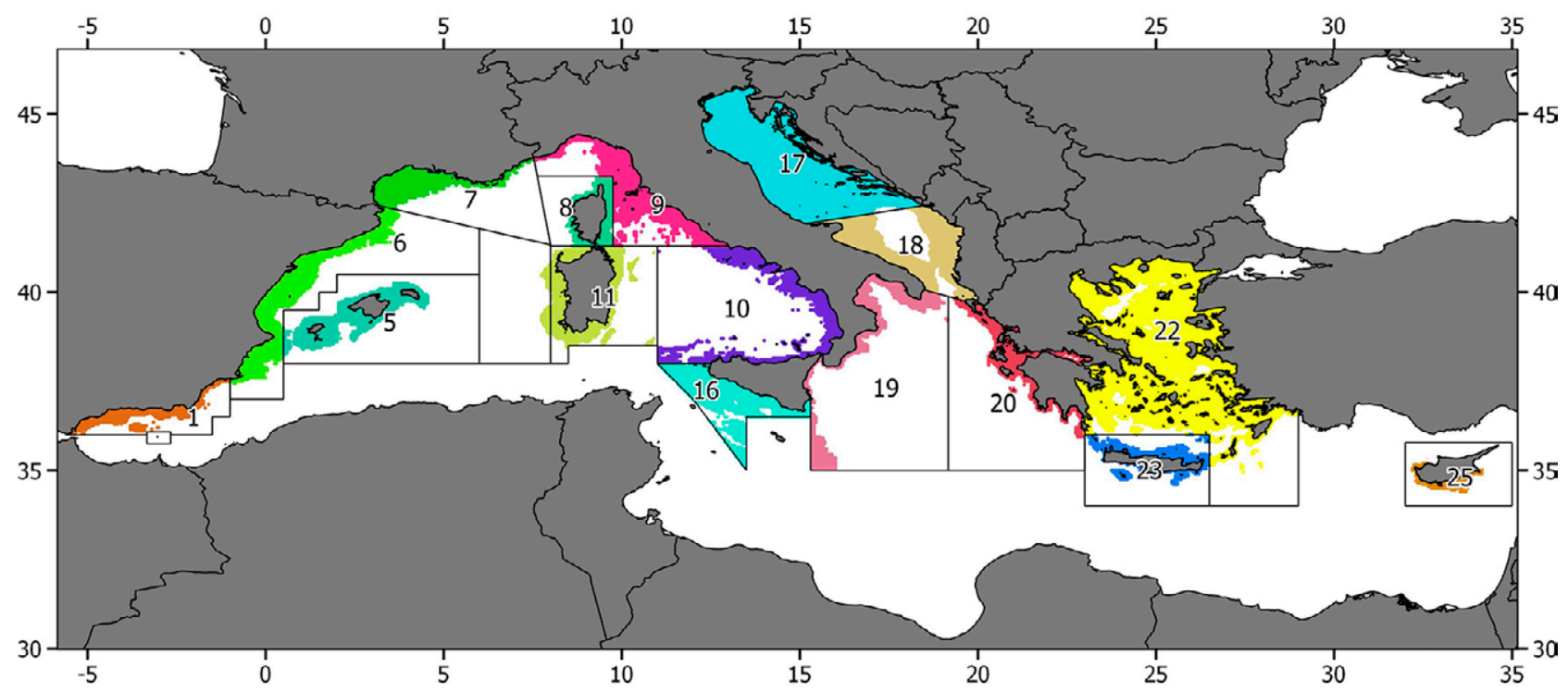

Fig. 1. - Map of the study area showing the sampling stations of the MEDITS surveys during the period 2012-2015 and numbers of the geographical sub-areas (GSAs) established by the General Fisheries Commission for the Mediterranean (GFCM). The names of the GSAs are shown in Table 1. 
ish (Guijarro et al. 2012, Barría et al. 2015, RamírezAmaro et al. 2015), Italian (Follesa et al. 2011, Ligas et al. 2013, Marongiu et al. 2017) and Greek waters (Maravelias et al. 2012, Tserpes et al. 2013). These studies have been carried out on the northern Mediterranean coast and very few have been carried out on the southern coast off Africa (e.g. Ordines et al. 2011).

The aim of this work is to give updated information on the distribution and abundance of demersal chondrichthyans on a wide Mediterranean scale and to compare findings among different areas in relation to environmental factors. Abundance indices and frequency of occurrence of the species were estimated from data obtained from the International Mediterranean Trawl Survey (MEDITS), which aims to produce information on population distribution and demographic structure of demersal species inhabiting the continental shelf and the upper slope (Bertrand et al. 2002). Thanks to the adoption of a common standardized sampling protocol, this scientific survey provides comparable speciesspecific data in several parts of the Mediterranean.

\section{MATERIALS AND METHODS}

The data were collected during the bottom trawl MEDITS surveys, which have been performed annually in spring-summer since 1994 . This research programme involves several institutes and teams across different geographical sub-areas (GSAs) established by the GFCM. More specifically, data of chondrichthyans at species level were provided by 16 GSAs from 9 different countries (Spain, France, Italy, Slovenia, Croatia, Albania, Montenegro, Greece and Cyprus), covering wide areas of the western, central and eastern Mediterranean (Table 1; Fig. 1). Considering that not all chondrichthyan species were included in the list of MEDITS target species until 2008, there were no complete data time series available for all study areas. For this reason, only data of four recent years (from 2012 to 2015) were analysed. For the Greek GSAs (20, 22 and 23), data were available only for the year 2014, as the MEDITS survey was performed only in this year.

As described in the MEDITS Handbook (Anonymous 2017), these surveys were carried out from May to July, with the exception of 2015 when some Italian GSAs postponed the survey to early autumn due to bureaucratic problems. Samples were taken during daylight using the experimental bottom trawl GOC-73, with $10 \mathrm{~mm}$ cod-end mesh size, which corresponds to a mesh opening of about $20 \mathrm{~mm}$. This gear was specially designed to be highly selective in all sampled areas and depths, allowing a representative sampling of demersal megafauna species. Sampling station selection was based on a stratified sampling scheme including five bathymetric strata: $10-50 \mathrm{~m}, 51-100 \mathrm{~m}, 101-200 \mathrm{~m}$, 201-500 $\mathrm{m}$ and 501-800 m, except for GSA 17 in which the deepest stratum was not present. The duration of hauls was 30' at stations at less than $200 \mathrm{~m}$ depth and 60 ' at deeper stations. The number and weight of all specimens captured were recorded. For each species, the frequency of occurrence within their preferential

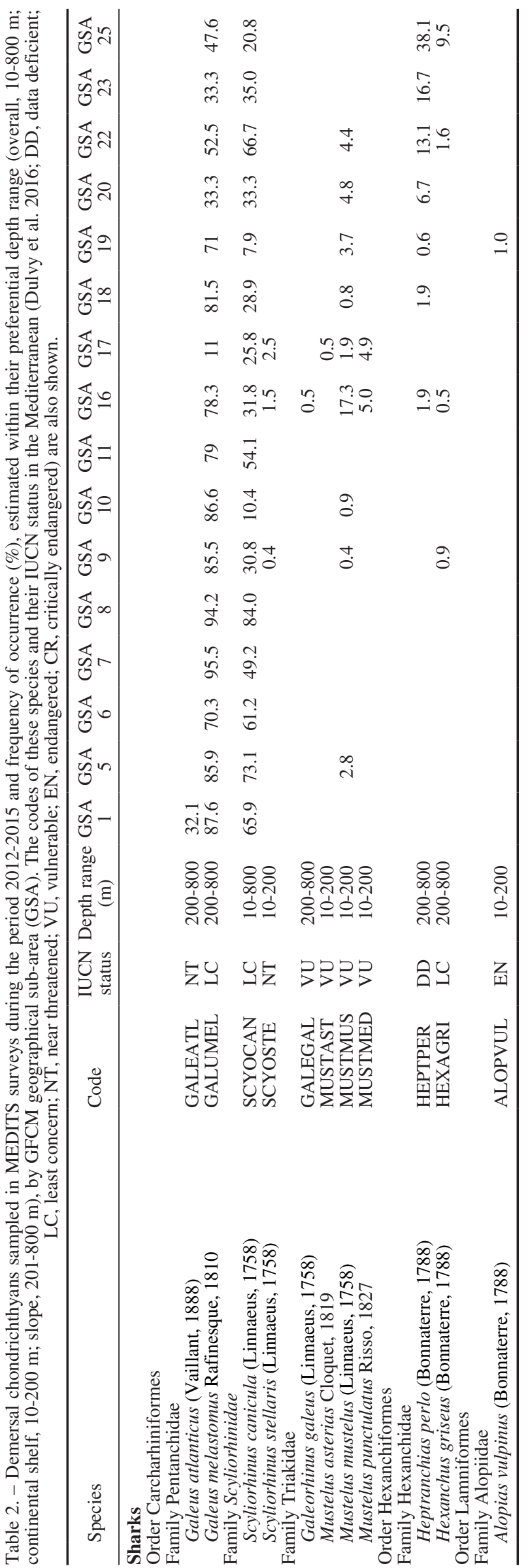




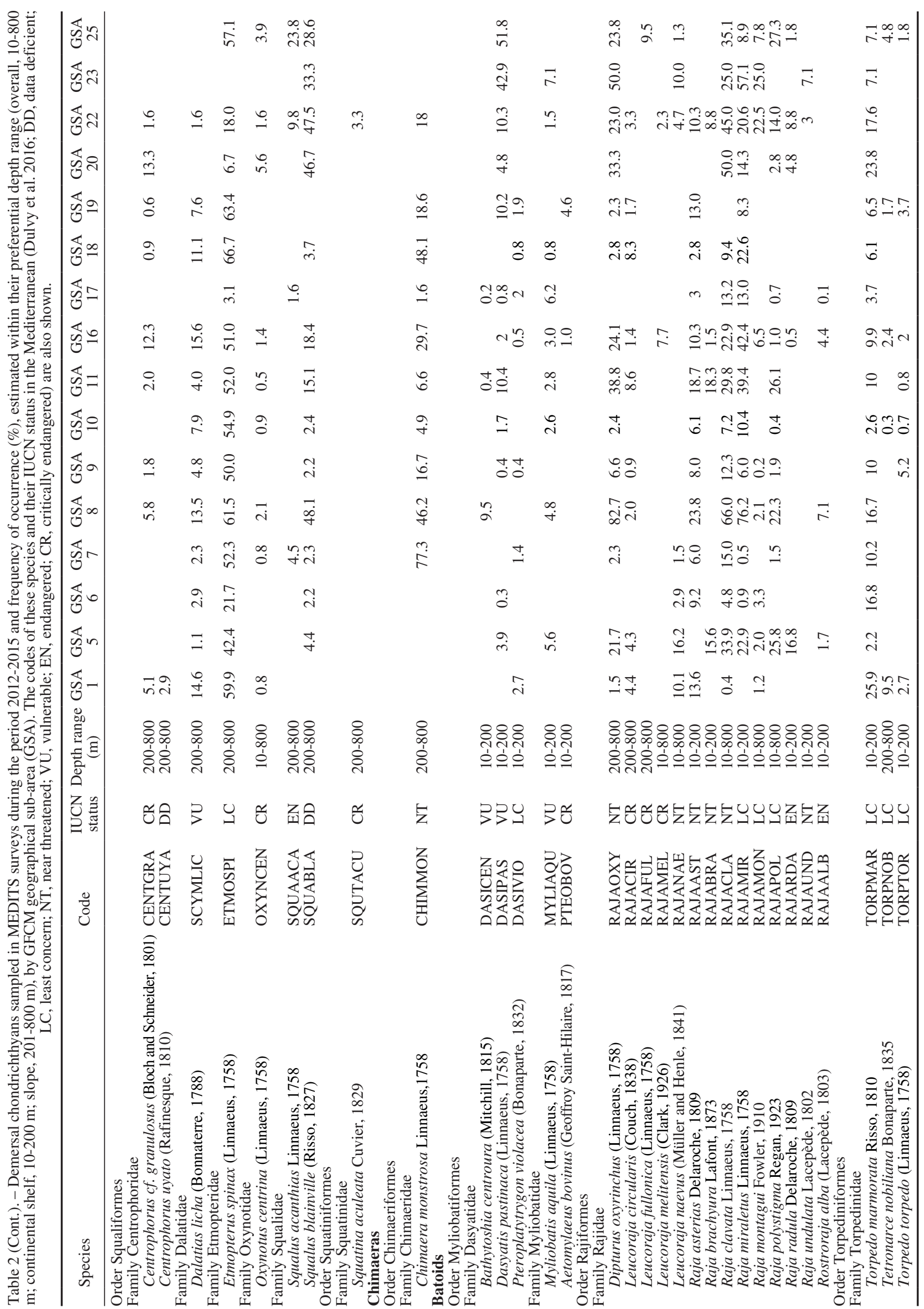


depth range was calculated by GSAs as percentage of hauls where it was present in respect to the total hauls of the stratum during the four-year study period (Table 2 ). Abundance indexes (biomass index as B in $\mathrm{kg} \mathrm{km}^{-2}$ and density index as D in ind. $\mathrm{km}^{-2}$ ) were calculated for each species by GSAs for the following depth ranges: overall range $(10-800 \mathrm{~m})$, continental shelf $(10-200 \mathrm{~m})$ and slope (201-800 m).

\section{GAM analysis}

For each haul, biomass $\left(\mathrm{kg} \mathrm{km}^{-2}\right)$ and density (ind. $\mathrm{km}^{-2}$ ) indexes were calculated for two species groups (sharks and batoids) and then modelled separately by generalized additive models (GAMs). The variables to be included in the GAM analysis were checked first for the variance inflation factor (VIF) and then for the correlations with the other variables from the Pearson correlation coefficient. The variables were then selected considering whether the contribute of each variable was significant for the improvement of the model's fit and also whether the estimation of the variables' smoothing term was significant.

In each GAM model, the following explanatory variables were used: geographical coordinates (latitude and longitude), depth, sea surface temperature (SST) and sea bottom temperature (BotTemp). Depth derived from the EMODnet Bathymetry portal (http:/www. emodnet.eu) was post-processed with GIS software (QGIS Development Team 2017) to obtain the bottom slope layer. SST and BotTemp data were obtained from Copernicus portal (http://marine.copernicus.eu) and used as a mean value in spring-summer (the MEDITS survey period) in the four years considered (20122015). Covariates data were associated with sampling station by mean of QGIS software.

To assess collinearity, the VIF was used, and covariates showing VIF values greater than 3 and high Pearson's correlation coefficient $(r)$ ( $>0.5$; absolute value) were rejected (Zuur et al. 2010). The covariates were rejected from the analysis following three criteria: (i) if the estimated degrees of freedom of the variable was close to 1 ; (ii) if the interval of confidence was zero; and (iii) if the generalized cross-validation (GCV) score (Gu and Wahba 1991) decreased when the covariate was eliminated from the model.

Non-normally distributed data were log-transformed. The models were estimated with the $m g c v$ library from R software (R Development Core Team 2018, Wood 2006) using the Gaussian distribution from the exponential family. The spatial analysis prediction was performed using a $0.03^{\circ}$ resolution grid and the resulting maps were produced with QGIS software (QGIS Development Team 2017).

\section{RESULTS}

Following the last taxonomic structure suggested by Eschmeyer et al. (2018), 41 species of chondrichthyans were detected from all the GSAs. They included 18 sharks ( 5 orders and 11 families), 22 batoids ( 3 orders and 4 families) and 1 chimaera (Table 2).

\section{Occurrence}

Except in some cases, batoids had a preferential distribution on the continental shelf (10-200 m depth), while sharks were more frequent on the slope (Table 2). Few species showed a wide distribution in all GSAs (Fig. 2): the sharks Galeus melastomus, with a frequency of occurrence between 201 and $800 \mathrm{~m}$ depth close to $90 \%$ in GSAs 1, 5, 9 and 10 and greater than $90 \%$ in GSAs 7 and 8, and Scyliorhinus canicula, with a frequency of occurrence in the whole depth range (10$800 \mathrm{~m}$ ) of $73 \%$ in GSA 5 and $84 \%$ in GSA 8; and the batoid T. marmorata, with the highest frequency of occurrence $(26 \%)$ in GSA 1 and the lowest $(2 \%)$ in GSA 5 (Table 2). Also in the eastern basin, the two sharks were the most present species, but with frequencies of occurrence lower than those recorded in the western basin: $52 \%, 33 \%$ and $48 \%$ in GSAs 22,23 and 25 , respectively, for G. melastomus and $67 \%, 35 \%$ and $21 \%$ in GSAs 22, 23 and 25, respectively, for S. canicula. $T$. marmorata showed a frequency of occurrence of $24 \%$ in GSA 20, similar to that obtained in GSA 1, but in the other GSAs of the eastern basin these values did not exceed $15 \%$ (Table 2).

Among Rajiformes, Raja clavata was present in all GSAs, except in GSA 19, showing the highest frequency of occurrence $(66 \%)$ in GSA 8 for the western basin and in GSAs 20 and 22 (50\% and 45\%, respectively) for the eastern basin, while the lowest one $(0.4 \%)$ was recorded in GSA 1 (Table 2, Fig. 2). Raja miraletus was representative of the central eastern Mediterranean, while Raja asterias showed higher values of occurrence in the western than in the eastern basin. By contrast, Raja undulata was rarely encountered in the central and eastern part of the Mediterranean, similarly to the Carcharhiniformes Mustelus asterias, Mustelus punctulatus and Scyliorhinus stellaris and the Myliobatiformes Bathytoshia centroura and Aetomylaeus bovinus (Table 2).

On the continental shelf, the most present species were $T$. marmorata and $R$. miraletus. On the slope, apart from the already mentioned $G$. melastomus, the Squaliformes Etmopteurs spinax was the second most sampled species, especially in the western and central basins, followed by Dipturus oxyrinchus and Squalus blainville, which showed a peak in GSA 8, with values of $83 \%$ and $48 \%$, respectively (Table 2, Fig. 2). A wide distribution was also shown for the deep water Dalatias licha and Chimaera monstrosa, while other species were more sparsely scattered throughout the Mediterranean. In particular, Galeus atlanticus was detected in a very restricted area of the western basin (GSA 1), but with an occurrence of $32 \%$, while Galeorhinus galeus was only found in GSA 16, with low occurrence $(0.5 \%)$. In the eastern basin, Leucoraja fullonica and Squatina aculeata were rare species (Table 2).

\section{Abundance}

Considering the overall depth range surveyed (10$800 \mathrm{~m}$ ), density (D) and biomass (B) values of sharks, batoids and the only chimaera were more variable be- 


\section{S. canicula}

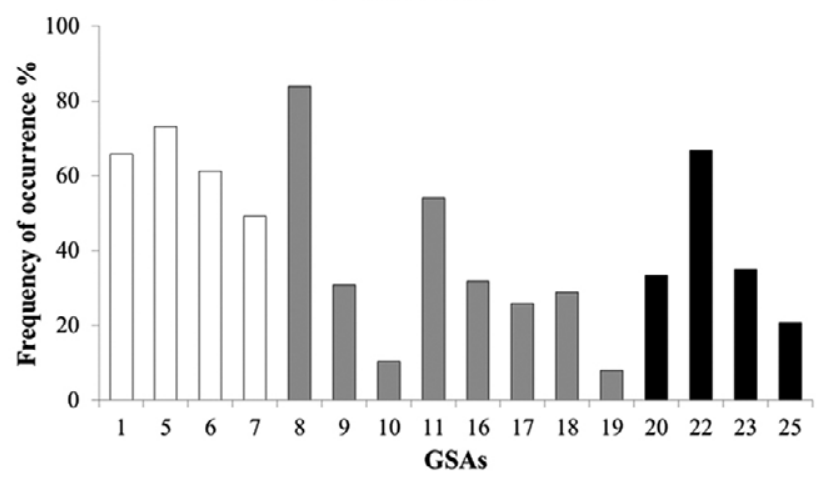

R. miraletus

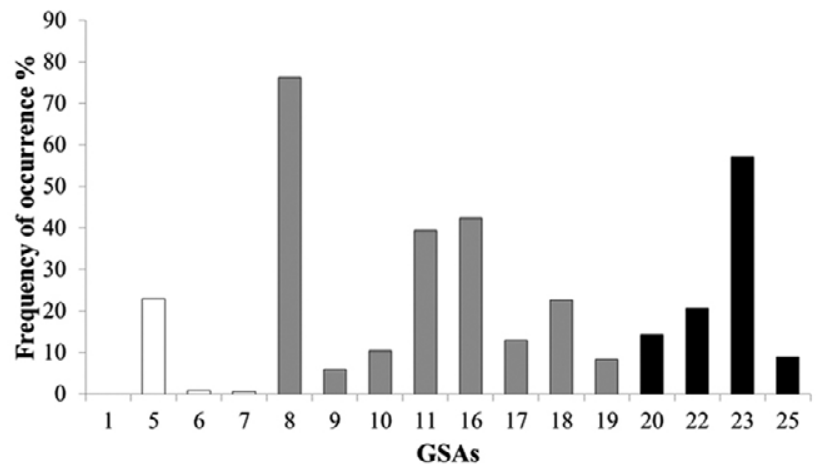

G. melastomus

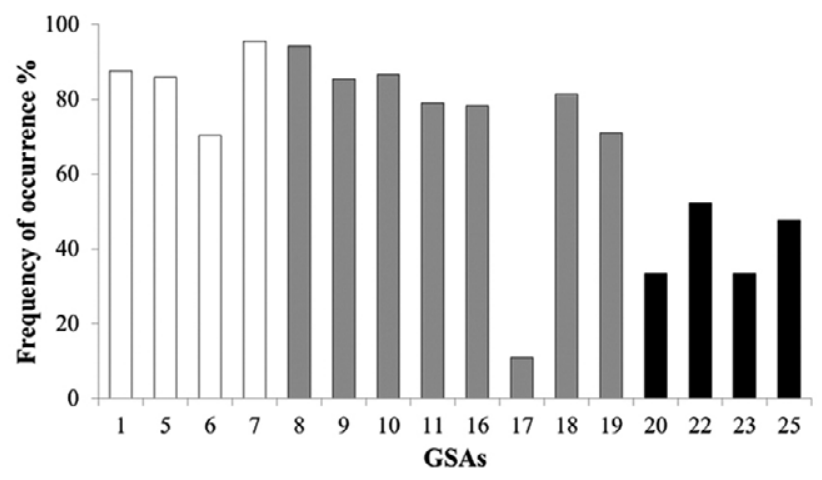

D. oxyrinchus

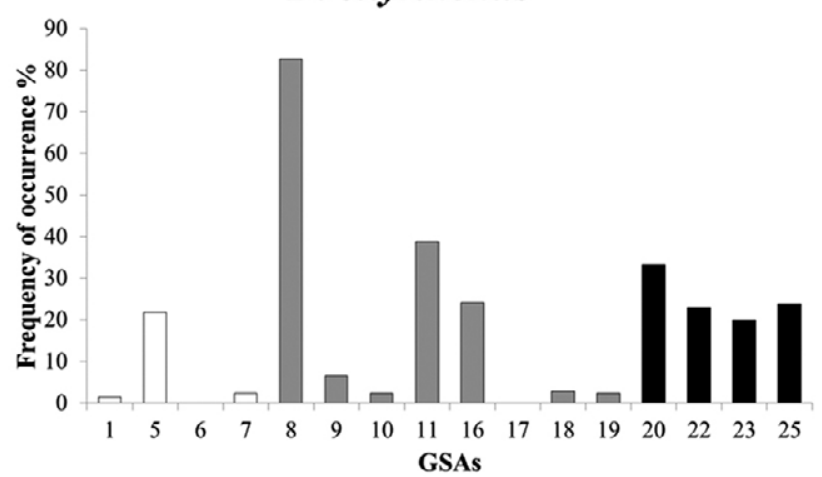

R. clavata

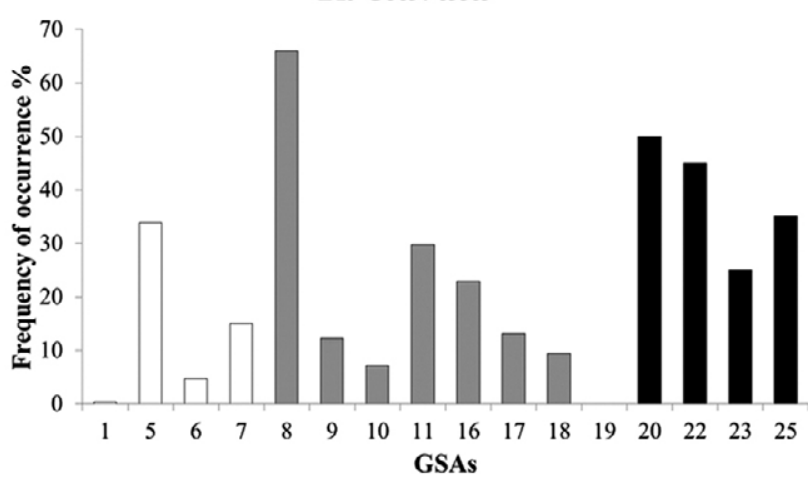

T. marmorata

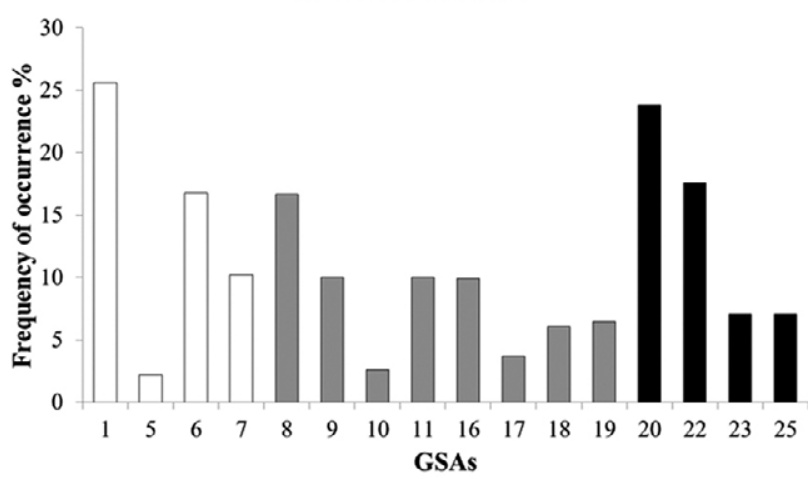

E. spinax

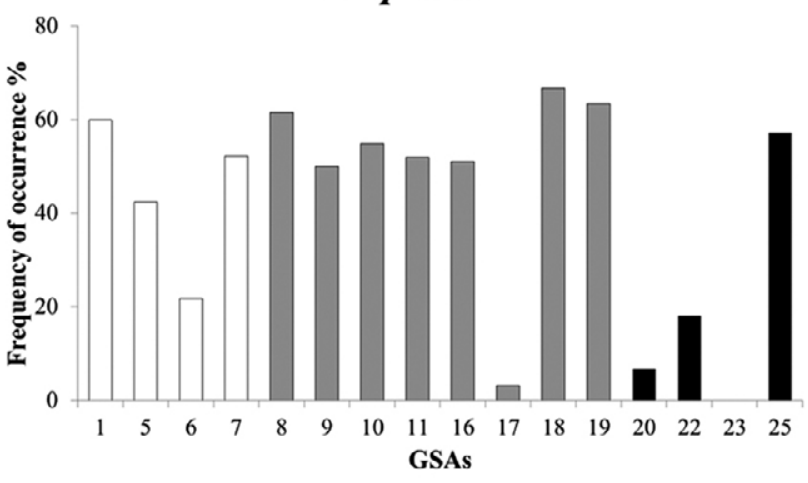

S. blainville

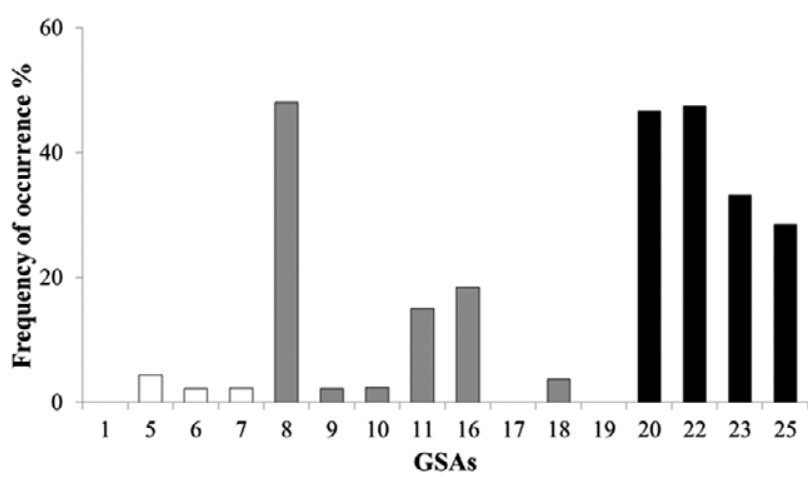

Fig. 2. - Frequency of occurrence by GFCM geographical sub-area (GSA) of the most common species of sharks and batoids within their preferential depth range: Scyliorhinus canicula and Raja clavata for the overall range (10-800 m); Raja miraletus and Torpedo marmorata for the continental shelf (10-200 m); and Galeus melastomus, Etmopterus spinax, Dipturus oxyrinchus and Squalus blainville for the slope (200-800 m). White bars, western GSAs; grey bars, central GSAs; black bars, eastern GSAs. 
88 - M.C. Follesa et al.

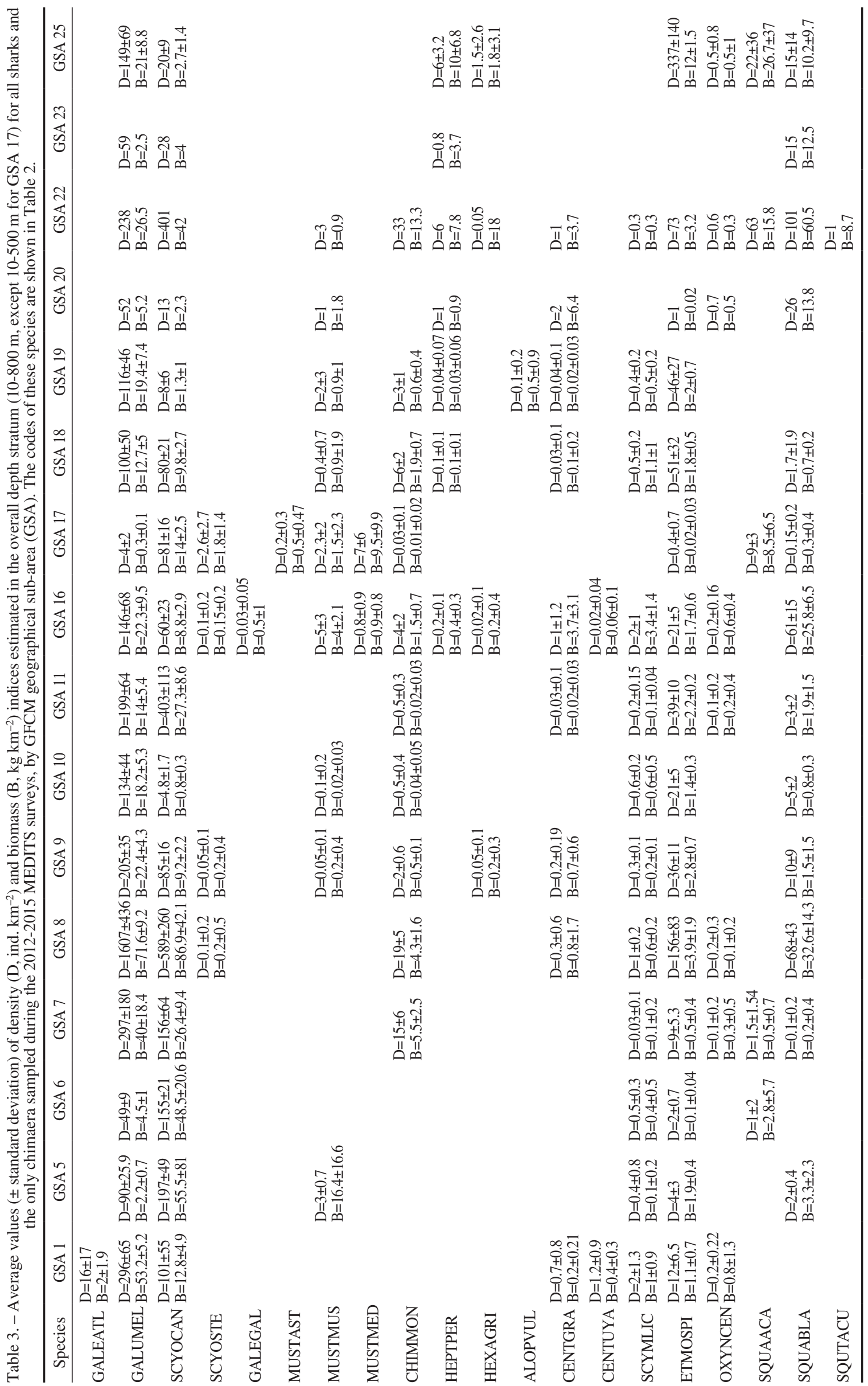




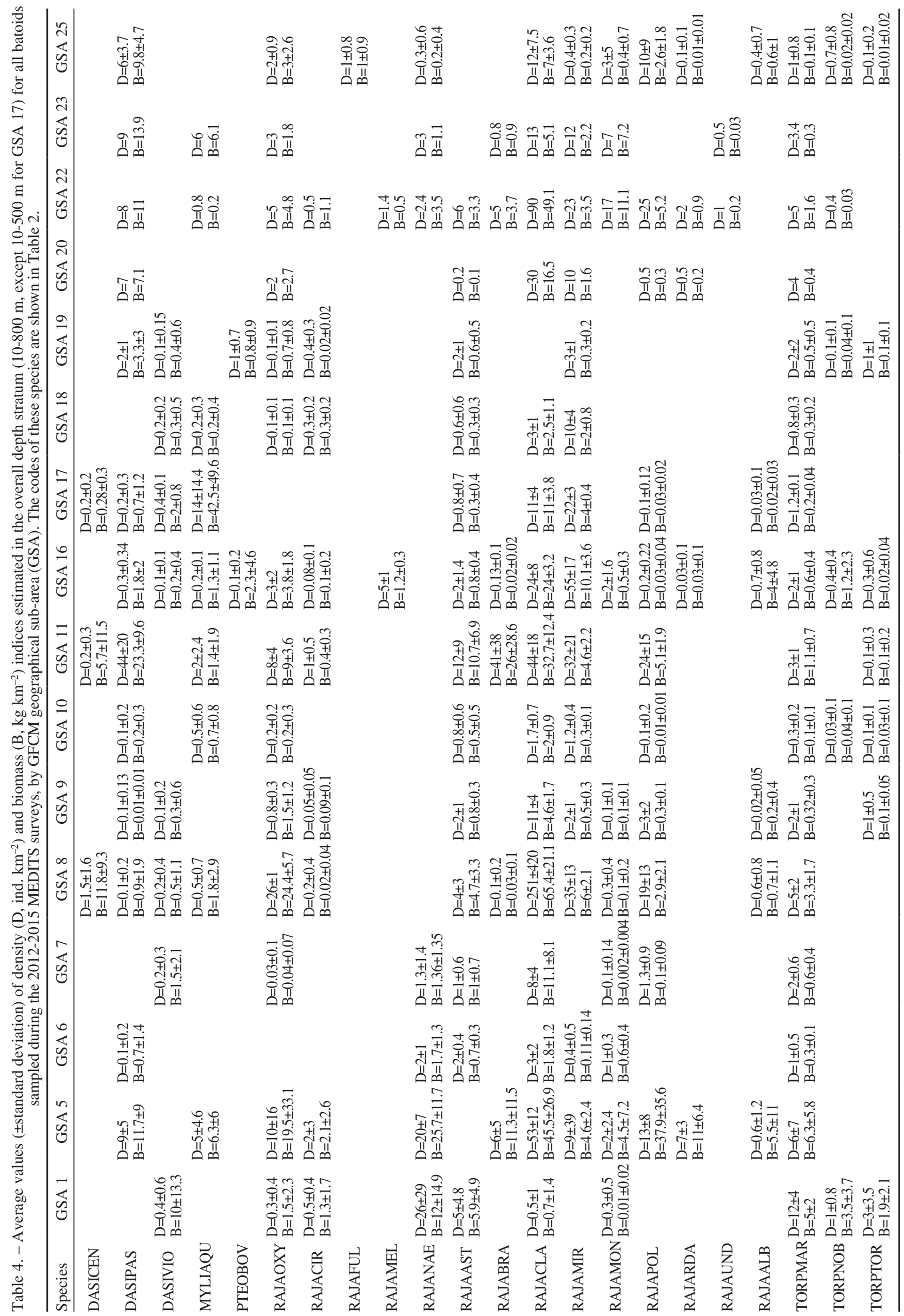


90 - M.C. Follesa et al.

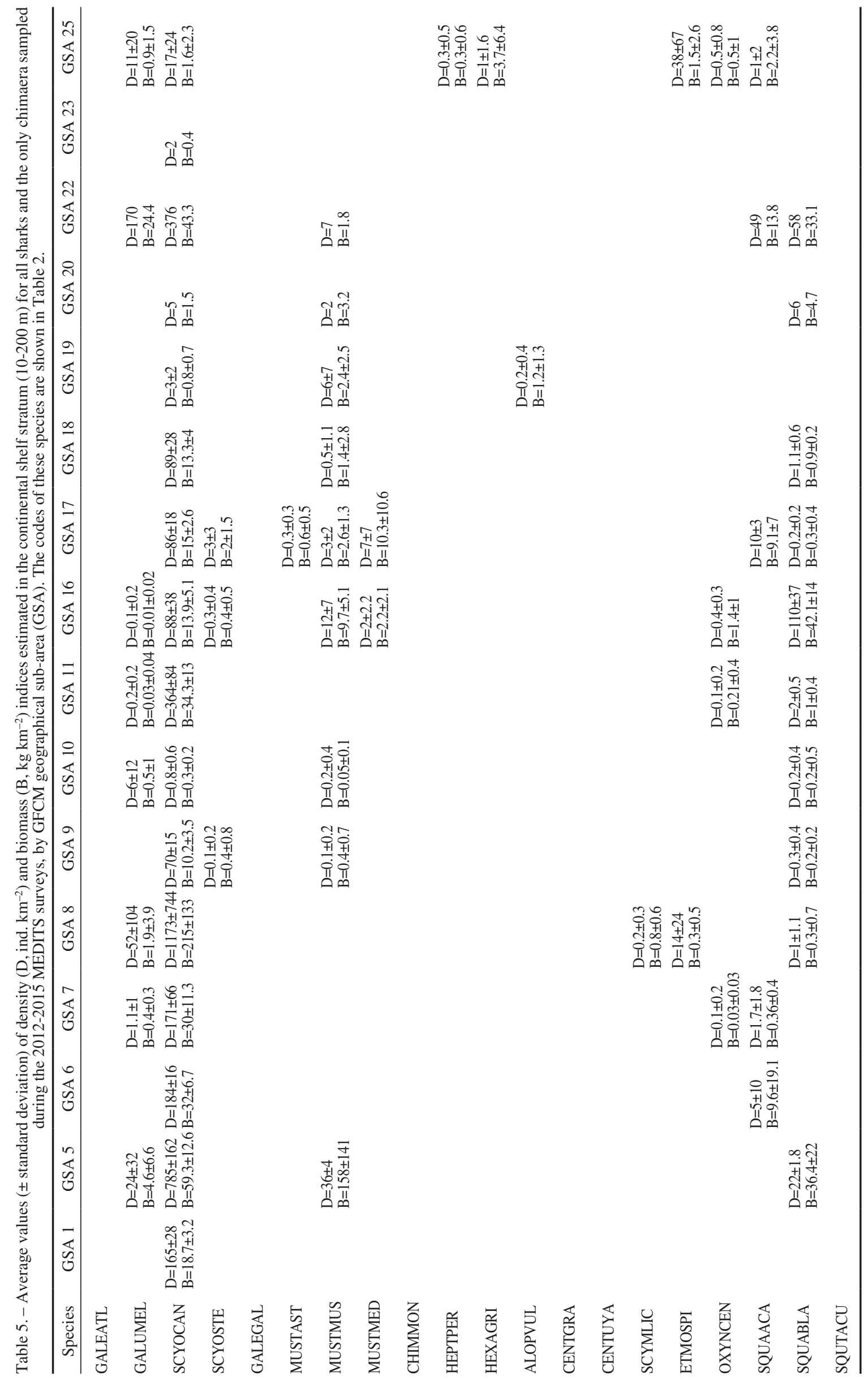

SCI. MAR. 83S1, December 2019, 81-100. ISSN-L 0214-8358 https://doi.org/10.3989/scimar.04998.23A 


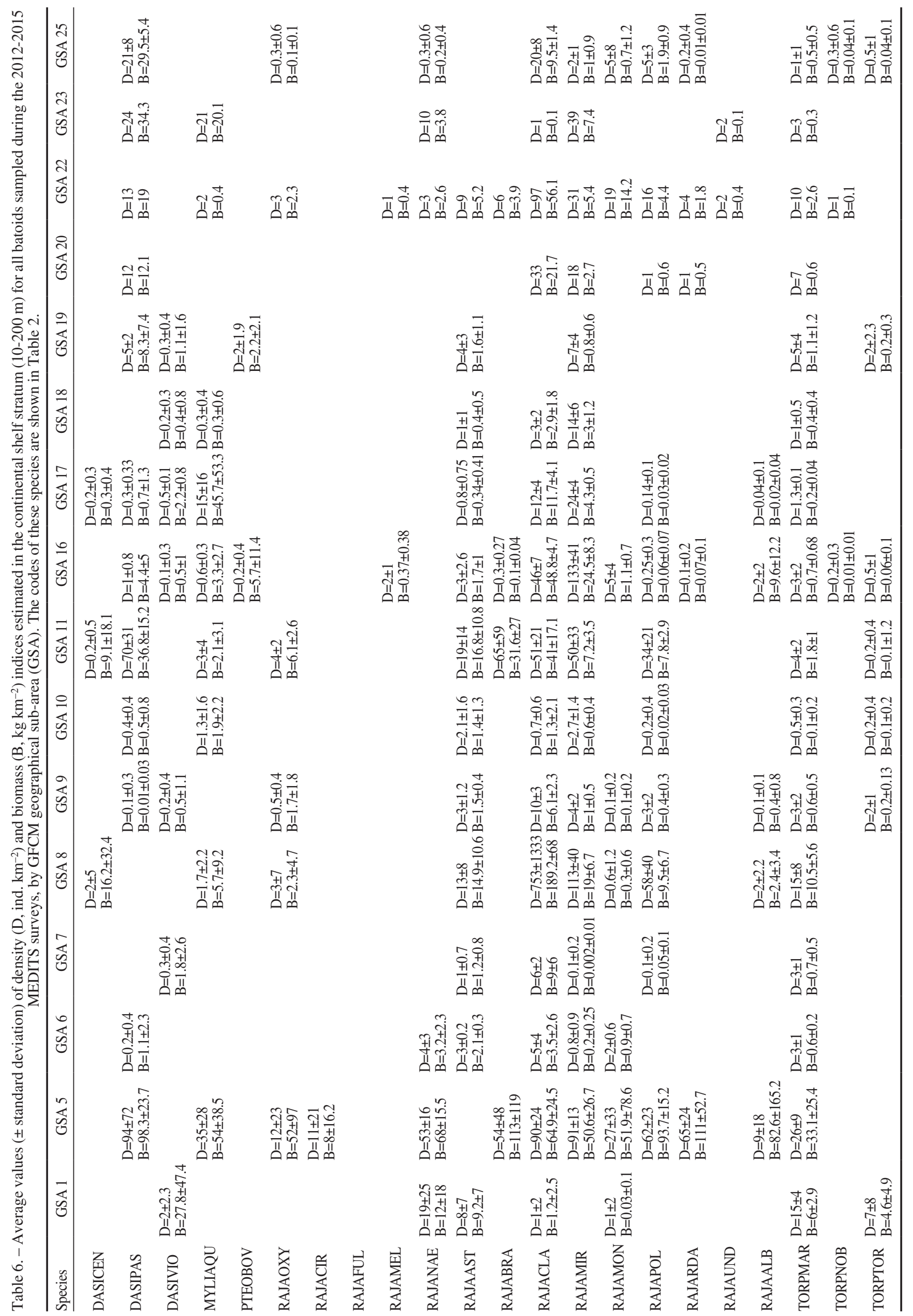


92 - M.C. Follesa et al.

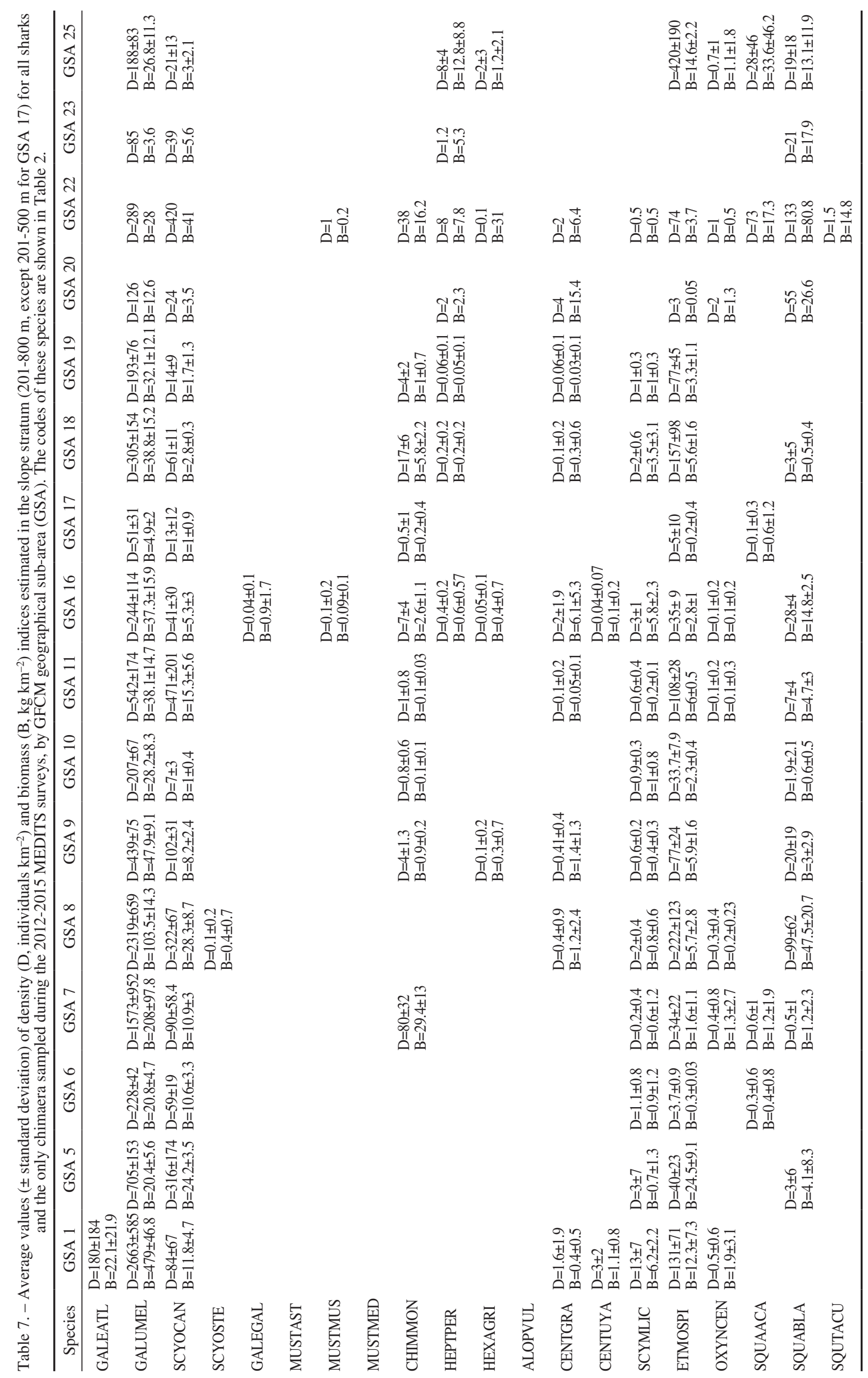

SCI. MAR. 83S1, December 2019, 81-100. ISSN-L 0214-8358 https://doi.org/10.3989/scimar.04998.23A 


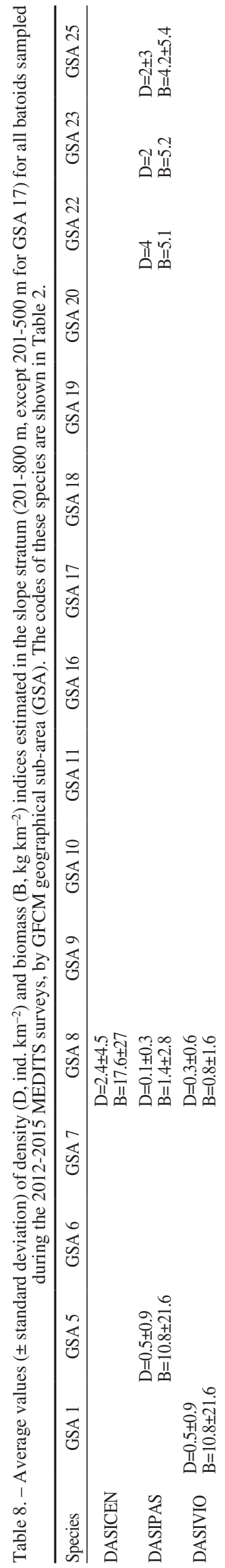

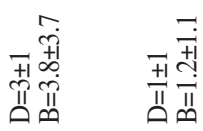

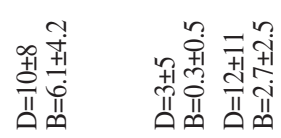

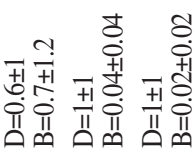

iㅔㅇㅠ

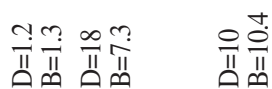

베에

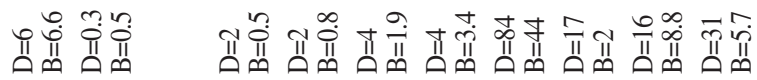

페에

范莣

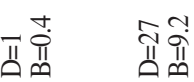

III

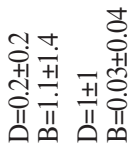

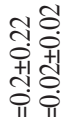

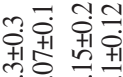

iㅣㅁiㅔㅇㅔ

解塗

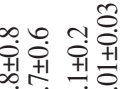

께에 $\pi$

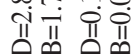

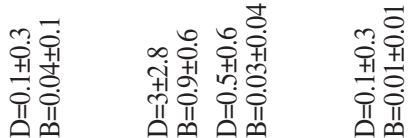

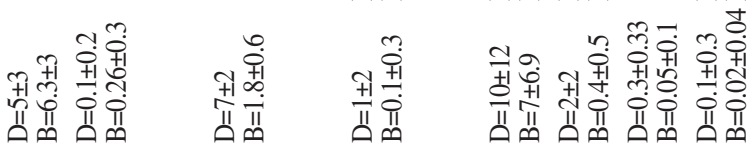

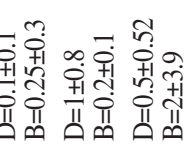

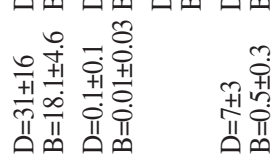

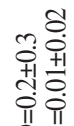

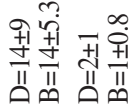

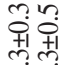

iㅔㅇㅔ

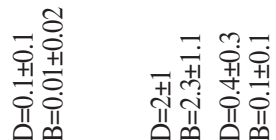

๓

譬语语

iㅔ에에에

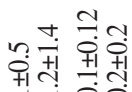

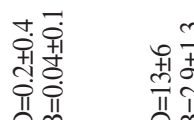

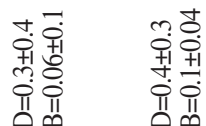

프레에

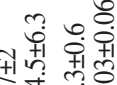

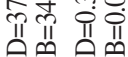

齐苹

iㅔㅇㅔ

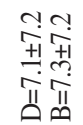

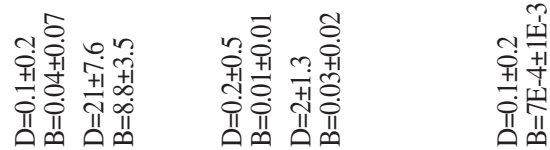

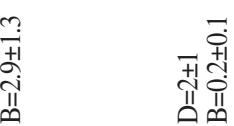

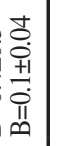

$$
\text { iㅔㅇㅔ }
$$

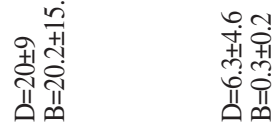

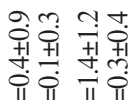

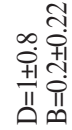

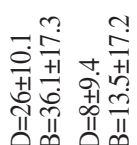

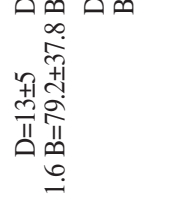

童

(1)

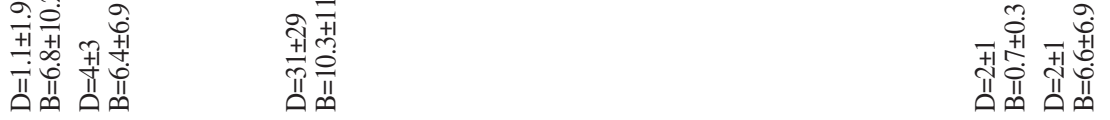

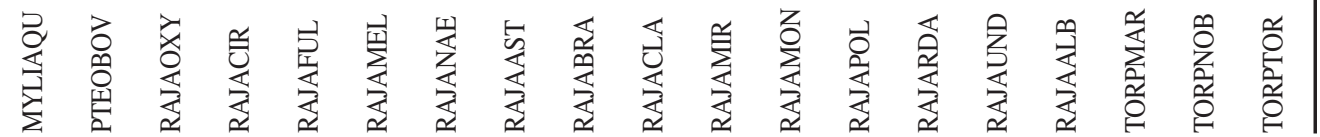




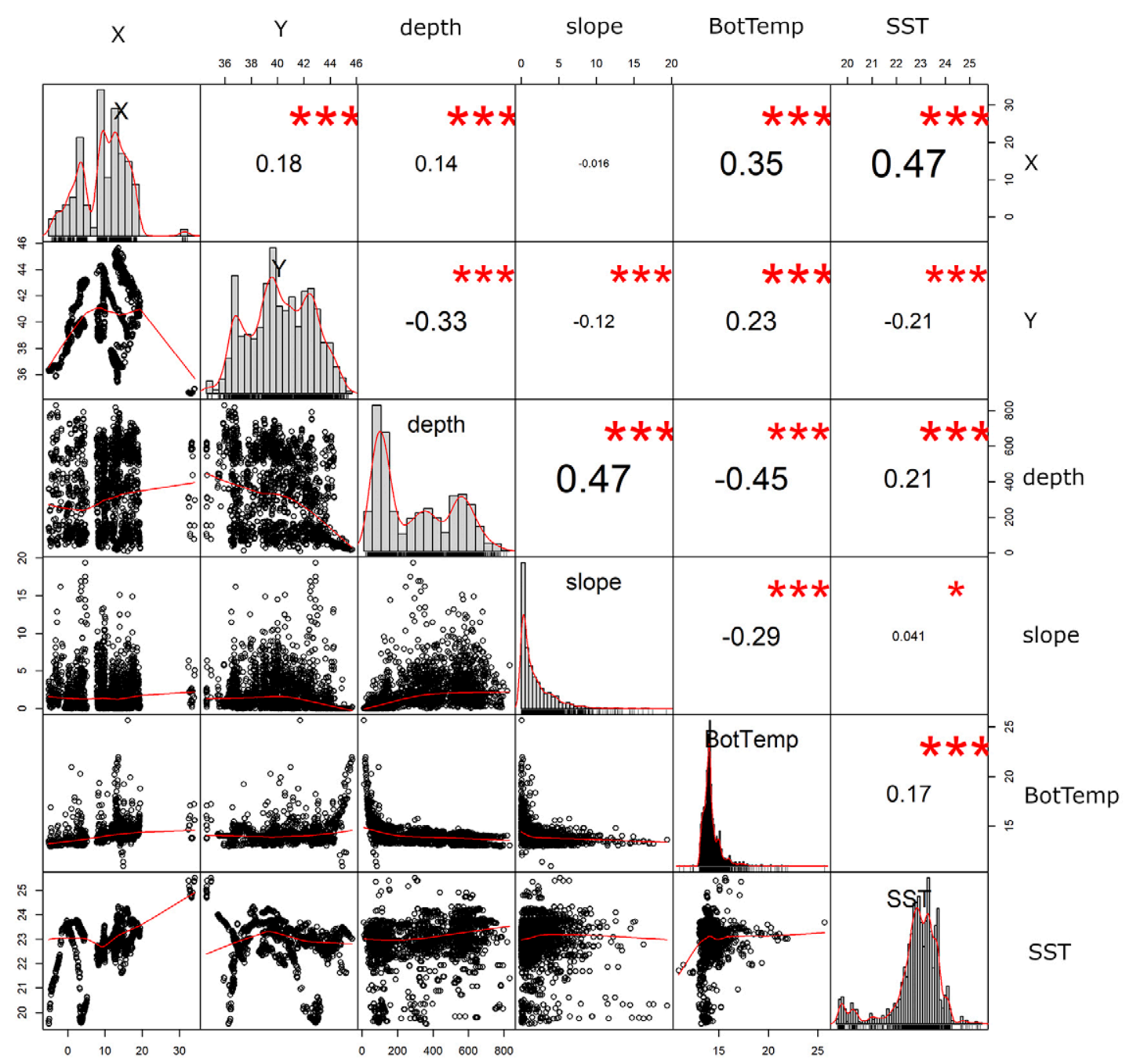

Fig. 3. - Pearson correlation matrix of the covariates used in GAM models for abundance of sharks (including also Chimaera monstrosa and Squatina aculeata) and batoids: Geographical coordinates (X: longitude; Y: latitude), depth, bottom slope, sea bottom temperature (BotTemp) and sea surface temperature (SST).

tween the GSAs (Tables 3 and 4). Two species mainly contributed to shark abundance in the basin (Table 3): G. melastomus, with the highest abundances in GSA8 (1607 \pm 35 ind. $\mathrm{km}^{-2}$ and $71.6 \pm 9.2 \mathrm{~kg} \mathrm{~km}^{-2}$ ) and the lowest ones in GSA 17 ( $4 \pm 2$ ind. $\mathrm{km}^{-2}$ and $0.3 \pm 0.1$ $\mathrm{kg} \mathrm{km}^{-2}$ ), and $S$. canicula, with the highest density $\left(589 \pm 260\right.$ ind. $\left.\mathrm{km}^{-2}\right)$ and biomass $\left(86.9 \pm 42.1 \mathrm{~kg} \mathrm{~km}^{-2}\right)$ in GSA8 and the lowest ones in GSA 10 (4.8 \pm 1.7 ind. $\mathrm{km}^{-2}$ and $\left.0.8 \pm 0.3 \mathrm{~kg} \mathrm{~km}^{-2}\right)$. The third most abundant shark was E. spinax (Table 3), with the highest values in GSA 25 (5337 140 ind. $\mathrm{km}^{-2}$ and $\left.12 \pm 1.5 \mathrm{~kg} \mathrm{~km}^{-2}\right)$ and the lowest ones in GSA $17\left(0.4 \pm 0.7\right.$ ind. $\mathrm{km}^{-2}$ and $0.02 \pm 0.03 \mathrm{~kg} \mathrm{~km}^{-2}$ ). Among batoids, $R$. clavata was the most abundant species, followed by $R$. miraletus (Table 4). Although T. marmorata was frequently encountered in all GSAs, its density and biomass were very low ( $\leq 12$ ind. $\mathrm{km}^{-2}$ and $\leq 6.3 \mathrm{~kg} \mathrm{~km}^{-2}$, respectively; Table 4).

Focusing on the continental shelf, apart from $S$. canicula, which was the most abundant chondrichthyan species caught in all GSAs (Tables 5 and 6), except for GSAs 10 and 19, this macro-stratum was characterized by the prevalence of batoids. Among these, the Rajidae family was the most abundant, being represented in primis by $R$. clavata and then by $R$. miraletus, $R$. polystigma and $R$. asterias (Table 6). T. marmorata reached lower values than the above species, as did Dasyatis pastinaca, which showed high values only in GSAs 5 and 11.

The slope, with a high abundance of sharks, is characterized by the abundance of $G$. melastomus in all GSAs (Tables 7 and 8), followed by S. canicula, E. spinax and $S$. blainville. Among batoids, the Rajidae family was mostly represented by $R$. clavata and $D$. oxyrinchus. Myliobatidae was the only family not present on the slope, while Dasyatidae and Torpedinidae were scanty (Table 8). The highest abundance of $C$.

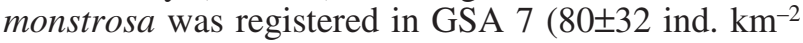
and $29.4 \pm 13 \mathrm{~kg} \mathrm{~km}^{-2}$ ). This species was not widespread throughout the Mediterranean (Table 7).

\section{GAM results}

The covariates tested for collinearity showed no VIF values greater than 3 and none of the Pearson correlation coefficients was greater than 0.5 (Fig. 3). 
Table 9. - GAM models for density (D, ind. $\mathrm{km}^{-2}$ ) and biomass (B, $\mathrm{kg} \mathrm{km}^{-2}$ ) indices of sharks (squa) and batoids (bat), considering geographical coordinates (Lon, Lat), depth, sea surface temperature (SST) and sea bottom temperature (BotTemp) as explanatory variables; $i$ is the index of the $i$-observation; $\alpha$ is the intercept; $\varepsilon_{i}$ is the error term; AIC is the Akaike information criterion; Dev. Expl. is the deviance explained.

\begin{tabular}{|c|c|c|}
\hline Model & AIC & Dev. Expl. (\%) \\
\hline $\log ($ D_squa $) \sim \alpha+\mathrm{f}_{i}\left(\right.$ Lon $_{i}$, Lat $\left._{i}\right)+\mathrm{f}_{i}\left(\right.$ depth $\left._{i}\right)+\mathrm{f}_{i}\left(\mathrm{SST}_{i}\right)+\mathrm{f}_{i}\left(\right.$ BotTemp $\left._{i}\right)+\varepsilon_{i}$ & 16494.2 & 58.3 \\
\hline $\log ($ B_squa $) \sim \alpha+\mathrm{f}_{i}\left(\operatorname{Lon}_{i}\right.$, Lat $\left._{i}\right)+\mathrm{f}_{i}\left(\right.$ depth $\left._{i}\right)+\mathrm{f}_{i}\left(\mathrm{SST}_{i}\right)+\mathrm{f}_{i}\left(\right.$ BotTemp $\left._{i}\right)+\varepsilon_{i}$ & 14561.8 & 49.2 \\
\hline $\log ($ D_bat $) \sim \alpha+\mathrm{f}_{i}\left(\operatorname{Lon}_{i}\right.$, Lat $\left._{i}\right)+\mathrm{f}_{i}\left(\right.$ depth $\left._{i}\right)+\mathrm{f}_{i}\left(\mathrm{SST}_{i}\right)+\mathrm{f}_{i}\left(\right.$ BotTemp $\left._{i}\right)+\mathrm{f}_{i}\left(\right.$ slope $\left._{i}\right)+\varepsilon_{i}$ & 15318.3 & 43.8 \\
\hline $\log ($ B_bat $) \sim \alpha+\mathrm{f}_{i}\left(\operatorname{Lon}_{i}\right.$, Lat $\left._{i}\right)+\mathrm{f}_{i}\left(\right.$ depth $\left._{i}\right)+\mathrm{f}_{i}\left(\mathrm{SST}_{i}\right)+\mathrm{f}_{i}\left(\right.$ BotTemp $\left._{i}\right)+\mathrm{f}_{i}\left(\right.$ slope $\left._{i}\right)+\varepsilon_{i}$ & 14712.9 & 41.2 \\
\hline
\end{tabular}
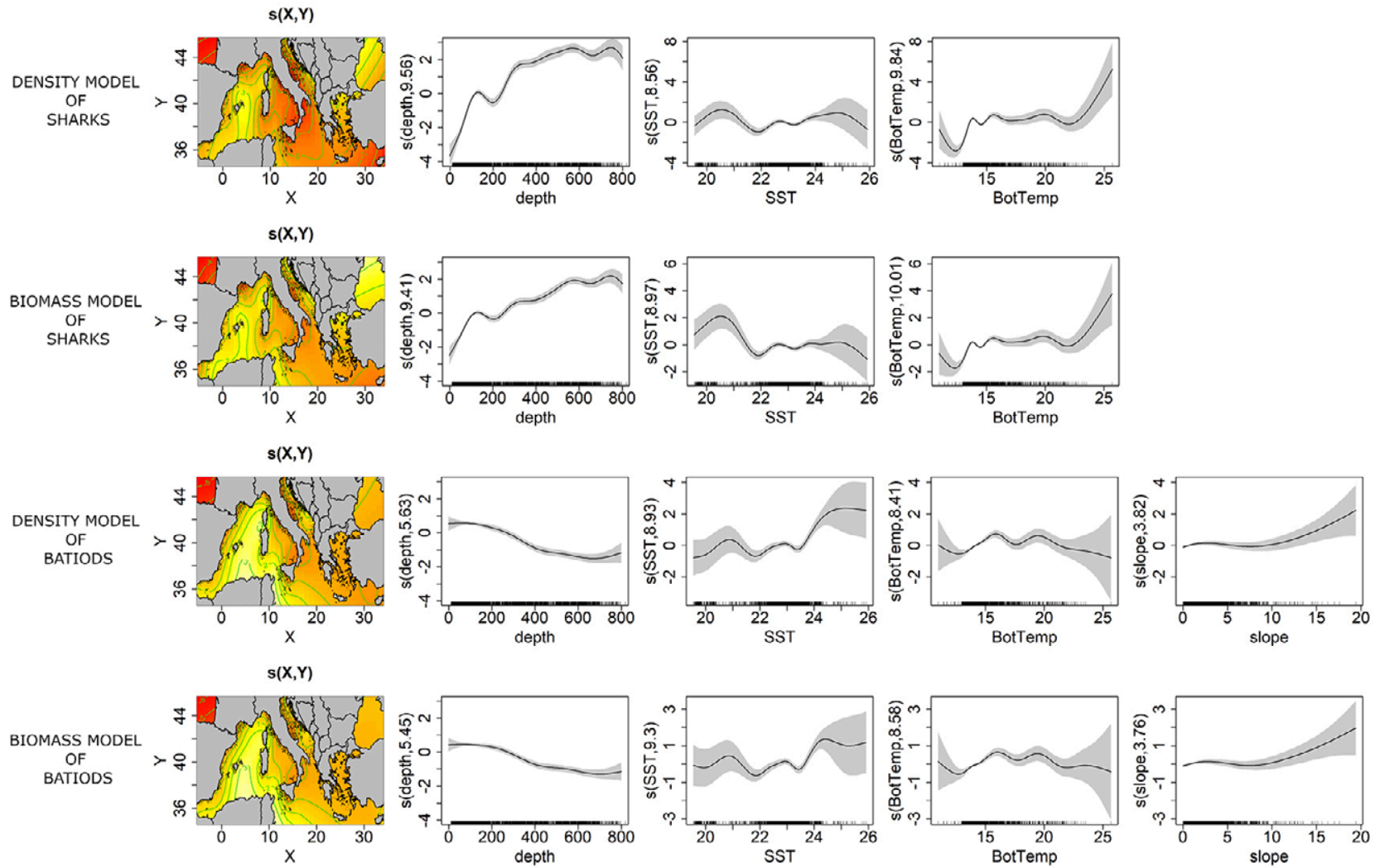

Fig. 4. - Smoother for the covariates estimated from GAM models for abundance of sharks and batoids: depth, sea surface temperature (SST), sea bottom temperature (BotTemp) and bottom slope.

As no collinearity was detected, none of the covariates was rejected from the model analysis. The bottom slope was not used in the models for sharks, as the estimated degrees of freedom values were close to one, giving no contribution to the improvement of the GCV and Aikake information criterion values of the models. The estimated degrees of freedom of the estimated smoothers used in each model were significantly different from zero ( $\mathrm{p}$-value $<0.05$ ).

The best models for abundance of both sharks and batoids are shown in Table 9 and Figure 4. The residuals of the models were tested with the Shapiro-Wilk normality test $(\mathrm{p}<0.05)$. Although the residuals of all the models were not normally distributed (Fig. 5), they could be considered symmetric enough as their skewness index was in the \pm 1 range (Hair et al. 2010). The predictive maps resulting from the models are shown in Figure 6.

In each group of species, the effect of the covariates is quite the same between density and biomass (Fig. 4). Depth was the most important driver influ- encing the distribution of both sharks and batoids, but the models described a different pattern for each group. Density and biomass of sharks increased with depth, the highest values of the response variables being estimated around the Balearic Islands (GSA 5), off the northeastern Iberian Peninsula (GSA 6), the eastern coast of Corsica (GSA 8), the northeastern coast of Sardinia (GSA 11), the northern part of GSA 16 , the southern part of GSA 19, around the pit of Bari in GSA 18 and the northern part of GSA 22. The models for batoids showed a very similar distribution pattern to that of sharks, but with hotspots at lower depth. The highest values of the response variables were estimated close to the Balearic Islands (GSA 5), off eastern Corsica (GSA 8), off northern Sardinia (GSA 11) and in the Strait of Sicily (GSA 16). Temperature had a significant influence in the species distribution, but with an opposite pattern in the two groups. The SST was lower in the areas of highest biomass of sharks than in the areas of highest biomass of batoids. 


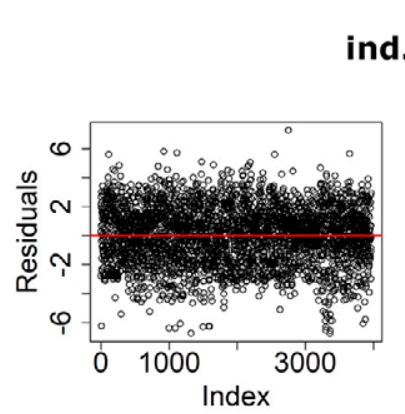

ind. $\mathrm{km}^{-2}$

SHARKS

skewness $=-0.24$

$\mathbf{k g ~} \mathbf{k m}^{-2}$
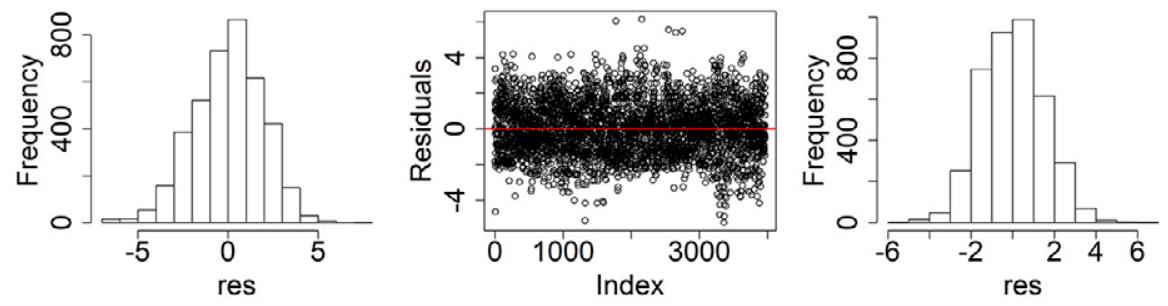

ind. $\mathrm{km}^{-2}$

\section{BATOIDS}

skewness $=0.1$

$\mathbf{k g ~} \mathbf{k m}^{-2}$
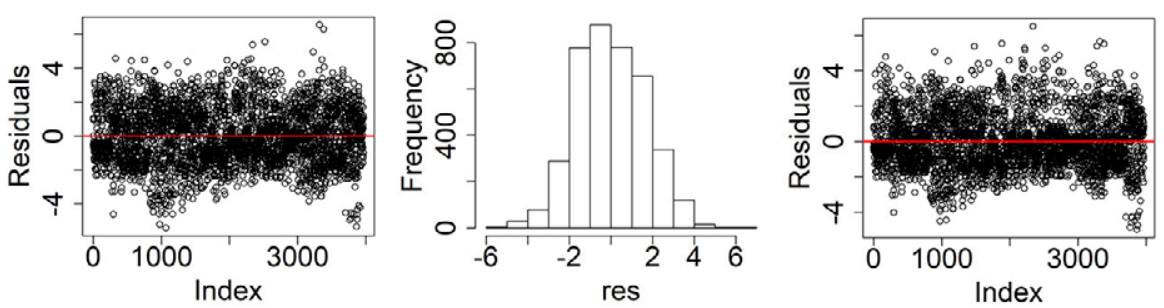

skewness $=0.45$

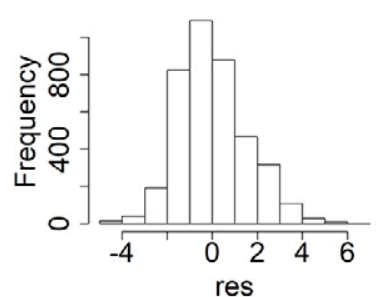

Fig. 5. - Plots and histograms of the residuals of GAM models for density (ind. $\mathrm{km}^{-2}$; left) and biomass $\left(\mathrm{kg} \mathrm{km}^{-2}\right.$; right) indices for sharks (top; including also Chimaera monstrosa and Squatina aculeata) and batoids (bottom).

\section{Sharks}
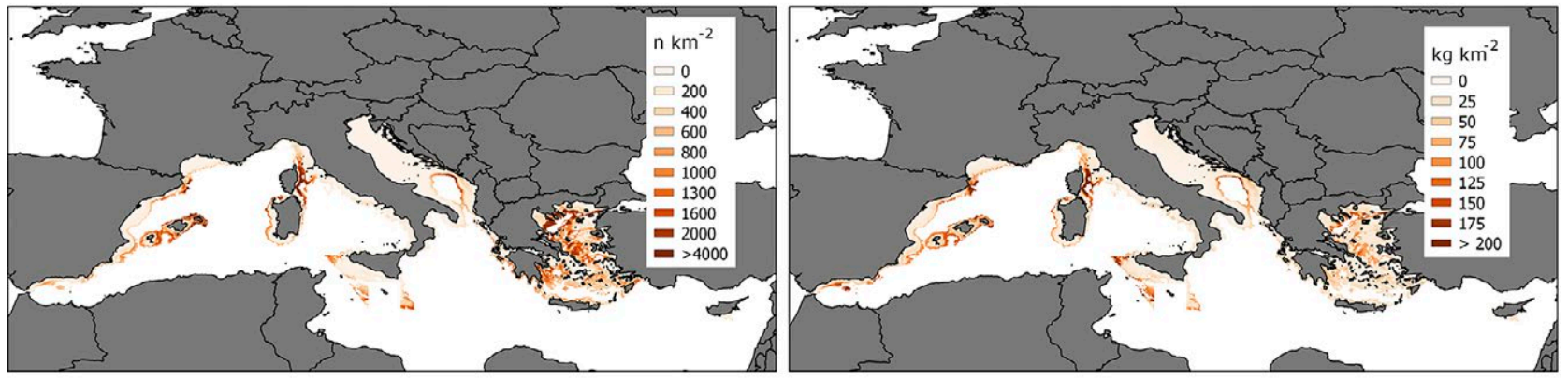

Batoids
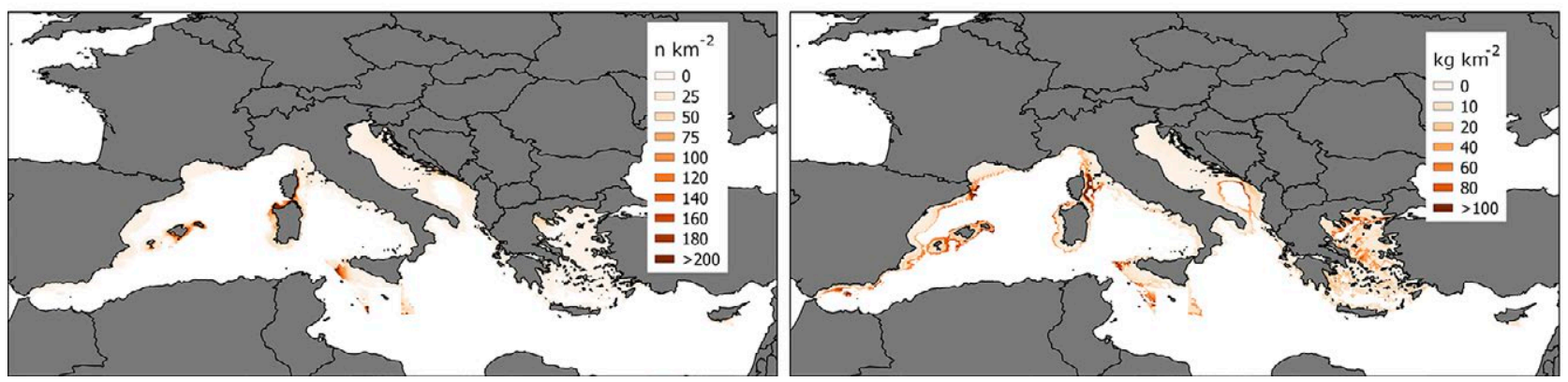

Fig. 6. - Maps from GAM models of density (ind. $\mathrm{km}^{-2}$; left) and biomass ( $\mathrm{kg} \mathrm{km}^{-2}$; right) indices for sharks (top; including also Chimaera monstrosa and Squatina aculeata) and batoids (bottom).

\section{DISCUSSION}

This work provides standardized and updated information regarding the distribution, occurrence and abundance of chondrichthyans along the whole northern Mediterranean, from west to east. Historically, their diversity has been considered greatest in the western basin, particularly in the coastal waters of Morocco,
Algeria, and Tunisia (between 57 and 69 species), and slightly lower in the northwestern countries, Spain (including the Balearic Islands), France and Italy, and in Greece. Intermediate levels of diversity have been reported for the central Mediterranean along the coasts of Libya, Malta and Sicily and in the coastal waters of the countries bordering the Adriatic and Aegean seas. This longitudinal gradient in the species richness 
of chondrichthyans has been suggested by several authors (Dulvy et al. 2016, Melendez et al. 2017, Bradai et al. 2018). However, the results of the present work seemed not to confirm this pattern (the Strait of Sicily and the Aegean showed the largest number of species), probably because North Africa is not involved in the MEDITS programme, so diversity in this area could not be considered.

Comparing our results with the literature, an abrupt decrease in the number of chondrichthyan species has been detected in the northern Adriatic (GSA 17): from 33 demersal, meso-predatory elasmobranchs in 1948 (Jukić-Peladić et al. 2001, Coll et al. 2009, Ferretti et al. 2013) to 20 species found in this study during recent years (2012-2015). This confirms the known structural depletion of the demersal community in terms of diversity during the last few decades.

A previous study conducted by Bertrand et al. (2000) involving almost the same GSAs sa those analysed in this work pointed out that the most widespread species in the basin were Scyliorhinus canicula, Galeus melastomus and Etmopterus spinax among sharks, Raja clavata, Raja miraletus, Raja asterias and Torpedo marmorata among batoids, and Chimaera monstrosa. From our results, the most frequent and abundant species all around the basin are S. canicula, G. melastomus and E. spinax among sharks and R. clavata and $R$. miraletus among batoids, partly confirming the findings of Bertrand et al. (2000) and other previous data present in literature for the western (Barría et al. 2015, Ramírez-Amaro et al. 2015, Marongiu et al. 2017), central (e.g. Jukić-Peladić et al. 2001, Bottari et al. 2014) and eastern (Tserpes et al. 2013) Mediterranean. The overlapping of observations should probably be attributed to the higher fishing pressure resilience of these species (Cavanagh and Gibson 2007). Usually, in spite of this resilience, fishing pressure should be considered as one of the main variables affecting the abundance of chondrichthyans, but not the only one (Frodella et al. 2016).

To parameterize fishing pressure is a big issue, particularly in terms of spatial distribution and at a large scale (Russo et al. 2017). In fact, although a spatial index of fishing pressure was recently developed at a regional scale in the Mediterranean (Kavadas et al. 2015), the only maps of the geographical distribution of trawling fishing pressure along the whole basin were drawn up by Sbrana et al. (2013). The comparison between these maps and our results shows that the areas under higher fishing pressure, such as the Adriatic and the Spanish coast (with the exception of the Balearic Islands) show low abundance of chondrichthyans, but other areas with a high level of fishing pressure, such as southwestern Sicily, show a high abundance of these species. This finding suggests that other environmental drivers work together with fishing pressure to shape their distribution.

Some differences must be noted between our results and those of Bertrand et al. (2000), especially regarding the decline of $C$. montrosa. This species seemed not so widespread as in the past years. A possible explanation for this decline, besides its rarity, could be found in the fact that this bathyal species has a lower degree of survival after discarding than other chondrichthyans (Ferretti et al. 2005). Among the rare or non-common species found in our analysis, the order Squatiniformes deserves particular attention. In the last century, angelsharks (Squatina spp.) were common in Mediterranean waters (Ferretti et al. 2005). Fortibuoni et al. (2016) reported that Squatina squatina was commonly sold in the main fish markets until the collapse of this species during the 1960s led to its disappearance in the northern Adriatic. Furthermore, Damalas and Vassilopoulou (2011) underlined the absence of the two other species of angelsharks, Squatina aculeata and Squatina oculata in the Aegean Sea, reporting that they had not been present in the catches for a couple of years. Our study shows that the only species of angelsharks caught during recent years is $S$. aculeata, whose presence has been detected in the same area. This fact could be a clear sign of decline or indicate a possible risk of extinction of this and the other two congeners in the Mediterranean, although, fortunately, interviews with fishermen reveal that this species seems not to have been extirpated yet, as was also observed in the Tyrrhenian (Ligas et al. 2013).

Some authors have reported the spiny dogfish $(S q$ ualus acanthias) to be one of the most frequent shark species captured in the Mediterranean (Baino et al. 2001, Serena et al. 2009, Damalas and Vassilopoulou 2011). Our results show its congener S. blainville to be the most abundant Squaliformes species throughout the basin, particularly in its central-western part (eastern Corsica and southern Sicily) and in the eastern Ionian and Aegean seas. Tsagarakis et al. (2013) also reported $S$. blainville to be one of the most important species of the demersal assemblages in the eastern Ionian Sea. The reason for this replacement between these two sharks could be related to taxonomic problems afflicting the Squalus genus and currently solved in different areas of the Mediterranean (Bonello et al. 2016, Bellodi et al. 2018). Indeed, recent studies (e.g. Anastasopoulou et al. 2018) highlight that $S$. acanthias showed a limited geographic distribution in the past, suggesting an inaccurate classification of these two species.

Focusing on macro-areas, previous findings regarding the distribution and abundance of chondrichthyan species conducted in Spanish and French seas (Massutí and Moranta 2003, Gouraguine et al. 2011, Ramírez-Amaro et al. 2015) are, in general, confirmed in the present work, with the highest number of species and abundance around the Balearic Islands. Regarding Italian seas, our data, as in a study conducted by Relini et al. (2000), confirmed the highest diversity of demersal chondrichthyans in the Strait of Sicily. Furthermore, G. melastomus and $S$. canicula were shown to be the most frequent and abundant shark species in Spanish and Italian waters, and $R$. clavata and $R$. miraletus were the most frequent and abundant batoids. In particular, $R$. clavata, with a large depth range, seemed to be more abundant off the Balearic Islands (GSA 5) and western Italy (GSAs 9, 10 and 11), where the slope is wide. $R$. miraletus, which is mostly widespread on 
sandy bottoms of the shelf, is also abundant around the Balearic Islands and off the central part of Italy (GSAs 16, 17, 18, 19), particularly in the northern Adriatic (GSA 17), where it is the most abundant skate. The low depth of this area, where the slope represents only $7 \%$ of its surface, explains the scant presence or the absence of the deep species E. spinax and G. melastomus, which are common in other GSAs, as also reported by Ferretti et al. (2013). The presence of the two Hexanchiformes Heptranchias perlo and Hexanchus griseus in Greek waters is probably due to the fact that they inhabit restricted and deep areas in favourable biological environments that are not exposed to a high fishing pressure, such as the Greek seas (Sion et al. 2004, El KamelMoutalibi et al. 2014, Rodríguez-Cabello 2018).

The modelling approach explored in this work has allowed us to produce useful maps to describe the distribution of demersal chondrichthyans in the Mediterranean following environmental drivers and mostly in terms of depth and temperature ranges. Within the current context of global warming, these environmental factors can play a pivotal role in the management and conservation of these species. However, taken into account their vulnerability to fishing exploitation, other factors such as fishing pressure should be incorporated in the future to obtain an exhaustive picture of the distribution, occurrence and abundance of chondrichthyan species inhabiting the Mediterranean. Considering their great number of species and abundance along northern African coasts, and the lack of time series of data available from these waters (Dulvy et al. 2016), the research surveys and investigations should be extended to the southern Mediterranean.

\section{ACKNOWLEDGEMENTS}

The MEDITS surveys have been carried out within the Data Collection Framework. The European Commission and Member States of the Mediterranean countries are thankfully acknowledged.

\section{REFERENCES}

Abella A.J., Serena F. 2005. Comparison of Elasmobranch Catches from Research Trawl Surveys and Commercial Landings at Port of Viareggio, Italy, in the Last Decade. J. Northw. Atl. Fish. Sci. 35: 345-356.

https://doi.org/10.2960/J.v35.m526

Anastasopoulou I., Mytilineou C., Makantasi P., et al. 2018. Life history aspects of two species of the Squalus genus in the Eastern Ionian Sea. J. Mar. Biol. Ass. U.K. 98: 937-948. https://doi.org/10.1017/S0025315416001818

Anonymous. 2017. MEDITS Handbook. Version n. 8, MEDITS Working Group, 177 pp.

Baino R., Serena F., Ragonese S., et al. 2001. Catch composition and abundance of elasmobranchs based on the MEDITS program. Rapp. Comm. Int. Mer Médit. 36: 234.

Barría C., Navarro J., Coll M., et al. 2015. Morphological parameters of abundant and threatened chondrichthyans of the northwestern Mediterranean Sea. J. Appl. Ichthyol. 31: 114-119. https://doi.org/10.1111/jai.12499

Bellodi A., Porcu C., Cau A., et al. 2018. Investigation on the genus Squalus in the Sardinian waters (Central-Western Mediterranean) with implications on its management. Medit. Mar. Sci. 19: $256-272$.

https://doi.org/10.12681/mms.15426
Bertrand J.A., Gil de Sola L., Papaconstantinou C., et al. 2000. An international bottom trawl survey in the Mediterranean: the Medits programme. In Bertrand J.A., Relini G. (eds). Demersal resources in the Mediterranean. Proceedings of the symposium held in Pisa, 18-21 March 1998. Actes de Colloques 26: 76- 93. Ifremer, Plouzané.

Bertrand J.A., Gil De Sola L., Papaconstantinou C., et al. 2002. The general specifications of the Medits surveys. Sci. Mar. 66: 9-17. https://doi.org/10.3989/scimar.2002.66s29

Bonello J., Bonnici L., Ferrari A., et al. 2016. Not all that clear cut: Intraspecific morphological variability in Squalus blainville (Risso, 1827) and implications for identification of the species. J. Mar. Biol. Assoc. U.K. 96: 1585-1596. https://doi.org/10.1017/S0025315415001915

Bornatowski H., Braga R.R., Vitule J.R.S. 2013. Shark mislabeling threatens biodiversity. Science 340: 923. https://doi.org/10.1126/science.340.6135.923-a

Bottari T., Busalacchi B., Profeta A., et al. 2014. Elasmobranch Distribution and Assemblages in the Southern Tyrrhenian Sea (Central Mediterranean). J. Aquac. Res. Develop. 5: 216. https://doi.org/10.4172/2155-9546.1000216

Bradai N.M, Saidi B., Enajjar S. 2018. Overview on Mediterranean Shark's Fisheries: Impact on the Biodiversity. In: Türkoğlu M., Önal U., Ismen A. (eds). Marine Ecology - Biotic and Abiotic Interactions. pp. 211-230. https://doi.org/10.5772/intechopen.74923

Camhi M.D., Fowler S.L., Musick J.A., et al. 1998. Sharks and their relatives: ecology and conservation. IUCN/SSC Shark Specialist Group, Gland, Switzerland and Cambridge, UK. iv + 39 pp.

Carbonell A., Alemany F., Merella P., et al. 2003. The by-catch of sharks in the western Mediterranean (Balearic Islands) trawl fishery. Fish. Res. 61: 7-18. https://doi.org/10.1016/S0165-7836(02)00242-4

Cariani A., Messinetti S., Ferrari A., et al. 2017. Improving the Conservation of Mediterranean Chondrichthyans: The ELASMOMED DNA Barcode Reference Library. PLoS ONE 12: e0170244. https://doi.org/10.1371/journal.pone.0170244

Cavanagh R.D., Gibson C. 2007. Overview of the conservation status of cartilaginous fishes (Chondrichthyans) in the Mediterranean Sea. IUCN, $42 \mathrm{pp}$.

Clarke S.C., McAllister M.K., Milner-Gulland E.J., et al. 2006. Global estimates of shark catches using trade records from commercial markets. Ecol. Lett. 9: 1115-1126. https://doi.org/10.1111/j.1461-0248.2006.00968.x

Coll M., Santojanni A., Palomera I., et al. 2009. Food-web changes in the Adriatic Sea over the last three decades. Mar. Ecol. Progr. Ser. 381: 17-37 https://doi.org/10.3354/meps07944

Colloca F., Enea M., Ragonese S., et al. 2017. A century fishery data documenting the collapse of smooth-hounds (Mustelus spp.) in Mediterranean Sea. Aquat. Conserv. 27: 1145-1155. https://doi.org/10.1002/aqc.2789

Compagno L.J.V. 1990. Alternative life-history styles of cartilaginous fishes in time and space. Env. Biol. Fish. 28: 33-75. https://doi.org/10.1007/978-94-009-2065-1 3

Damalas D., Vassilopoulou V. 2011. Chondrichthyan by-catch and discards in the demersal trawl fishery of the central Aegean Sea (Eastern Mediterranean). Fish. Res. 108: 142-152. https://doi.org/10.1016/j.fishres.2010.12.012

Davidson L.N.K., Krawchuk M.A., Dulvy N.K. 2016. Why have global shark and ray landings declined: Improved management or overfishing? Fish Fish. 17: 438-458. https://doi.org/10.1111/faf.12119

Dent F., Clarke S. 2015. State of the global market for shark products. FAO Fisheries and Aquaculture Technical Paper No. 590. Rome, FAO. 187 pp.

Dulvy N.K., Fowler S.L., Musick J.A., et al. 2014. Extinction risk and conservation of the world's sharks and rays. eLife 3: e00590. https://doi.org/10.7554/eLife.00590

Dulvy N.K., Allen D.J., Ralph G.M., et al. 2016. The conservation status of Sharks, Rays and Chimaeras in the Mediterranean Sea. IUCN, Malaga, Spain.

El Kamel-Moutalibi O., Mnasri-Sioudi N., Rafrafi-Nouira S., et al. 2014. Additional records of a rare elasmobranch species, sharpnose seven-gill shark Heptranchias perlo (Hexanchidae) off the northern Tunisian coast (Central Mediterranean). Ann. Ser. Hist. Nat. 2: 99-106.

Eschmeyer W.N., Fricke R., van der Laan R. (eds). 2018. Catalog of 
fishes: Genera, Species.

http://researcharchive.calacademy.org/research/ichthyology/ catalog/fishcatmain.asp

FAO. 2010. The state of world fisheries and Aquaculture 2010. Food and Agriculture organization of the United Nations. Rome, 197 pp.

FAO. 2016. The State of Mediterranean and Black Sea Fisheries. General Fisheries Commission for the Mediterranean. Rome, $134 \mathrm{pp}$.

Farrugio H., Oliver P., Biagi F. 1993. An overview of the history, knowledge, recent and future research trends in Mediterranean fisheries. Sci. Mar. 57: 105-119.

Ferretti F., Myers R.A., Serena F., et al. 2005. Long term dynamics of chondrichthyan fish community in the upper Tyrrhenian Sea. ICES CM Documents 25: 1-34.

Ferretti F., Worm B., Britten G.L., et al. 2010. Patterns and ecosystem consequences of shark declines in the ocean. Ecol. Lett. 13: 1055-1071. https://doi.org/10.1111/j.1461-0248.2010.01489x

Ferretti F., Osio G.C., Jenkins C.J., et al. 2013. Long-term change in a meso-predator community in response to prolonged and heterogeneous human impact. Sci. Rep. 3: 1057. https://doi.org/10.1038/srep01057

Follesa M.C., Porcu C., Cabiddu S., et al. 2011. Deep-water fish assemblages in the central-western Mediterranean (south Sardinian deep-waters). J. Appl. Ichthyol. 27: 129-135. https://doi.org/10.1111/j.1439-0426.2010.01567.x

Fortibuoni T., Borme D., Franceschini G., et al. 2016. Common, rare or extirpated? Shifting baselines for common angelshark, Squatina squatina (Elasmobranchii: Squatinidae), in the Northern Adriatic Sea (Mediterranean Sea). Hydrobiologia 772: 247-259. https://doi.oro/10.1007/s10750-016-2671-4

Fowler S.L., Reed T.M., Dipper F.A. 2002. Elasmobranch Biodiversity, Conservation and Management. Proceedings of the International Seminar and Workshop, Sabah, Malaysia, July 1997. IUCN SSC Shark Specialist Group, Gland, Switzerland and Cambridge, UK. 258 pp.

Frodella N., Cannas R., Velonà A., et al. 2016. Population connectivity and phylogeography of the Mediterranean endemic skate Raja polystigma and evidence of its hybridization with the parapatric sibling R. montagui. Mar. Ecol. Prog. Ser. 554: 99-113. https://doi.org/10.3354/meps 11799

General Fisheries Commission for the Mediterranean (GFCM). 2014. Report of the Workshop on elasmobranch conservation in the Mediterranean and Black Sea. Scientific Advisory Committee (SAC) of the General Fisheries Commission for the Mediterranean (GFCM). Sète, France, 10-12 December 2014. 26 pp.

Gouraguine A., Hidalgo M., Moranta J., et al. 2011. Elasmobranch spatial segregation in the western. Mediterr. Sci. Mar. 75: 653-664 https://doi.org/10.3989/scimar.2011.75n4653

Gu C., Wahba G. 1991. Minimizing GCV/GML Scores with Multiple Smoothing Parameters via the Newton Method. SIAM J. Sci. Stat. Comput. 12: 383-398. https://doi.org/10.1137/0912021

Guijarro B., Quetglas A., Moranta J., et al. 2012. Inter- and intraannual trends and status indicators of nektobenthic elasmobranchs off the Balearic Islands (northwestern Mediterranean). Sci. Mar. 76: 87-96. https://doi.org/10.3989/scimar.03432.22A

Hair J.F., Black W.C., Babin B.J., et al. 2010. Multivariate Data Analysis. Vectors. Pearson Ed. Ltd, Edinburgh

Heithaus M.R., Wirsing A.J., Dill L.M. 2012. The ecological importance of intact top-predator populations: a synthesis of 15 years of research in a seagrass ecosystem. Mar. Freshw. Res. 63: $1039-1050$ https://doi.org/10.1071/MF12024

Iglésias S.P., Toulhout L., Sellos D.P. 2010. Taxonomic confusion and market mislabelling of threatened skates: Important consequences for their conservation status. Aquat. Conserv. 20: 319-333. https://doi.org/10.1002/aqc.1083

Jukić-Peladić S., Vrgoč N., Krstulović-Šifner S., et al. 2001. Longterm changes in demersal resources of the Adriatic Sea. Comparison between trawl surveys carried out in 1948 and 1998. Fish. Res. 53: 95-104. https://doi.org/10.1016/S0165-7836(00)00232-0

Kavadas S., Maina I., Damalas D., et al. 2015. Multi-Criteria Decision Analysis as a tool to extract fishing footprints and estimate fishing pressure: application to small scale coastal fisheries and implications for management in the context of the Maritime Spatial Planning Directive. Mediterr. Mar. Sci. 16: 294-304. https://doi.org/10.12681/mms.1087

Kriwet J., Witzmann F., Klug S., et al. 2008. First direct evidence of a vertebrate three-level trophic chain in the fossil record. Proc. R. Soc. Lond, B. Biol. Sci. 275: 181-186. https://doi.org/10.1098/rspb.2007.1170

Lack M., Sant G. 2009. Trends in global shark catch and recent developments in management. TRAFFIC International. Cambridge, $33 \mathrm{pp}$.

Ligas A., Osio G.C., Sartor P., et al. 2013. Long-term trajectory of some elasmobranch species off the Tuscany coasts (NW Mediterranean) from 50 years of catch data. Sci. Mar. 77: 119-127. https://doi.org/10.3989/scimar.03654.21C

Maravelias C.D., Tserpes G., Pantazi M., et al. 2012. Habitat Selection and Temporal Abundance Fluctuations of Demersal Cartilaginous Species in the Aegean Sea (Eastern Mediterranean). PLOS ONE 7: e35474. https://doi.org/10.1371/journal.pone.0035474

Marongiu M.F., Porcu C., Bellodi A., et al. 2017. Temporal dynamics of demersal chondrichthyan species in the central western Mediterranean Sea: The case study in Sardinia Island. Fish. Res. 193: 81-94. https://doi.org/10.1016/j.fishres.2017.04.001

Massutí E., Moranta J. 2003. Demersal assemblages and depth distribution of elasmobranchs from the continental shelf and slope off the Balearic Islands (western Mediterranean). ICES J. Mar. Sci. 60: 753-766. https://doi.org/10.1016/S1054-3139(03)00089-4

Megalofonou P., Damalas D., Yannopoulos C. 2005. Composition and abundance of pelagic shark by-catch in the eastern Mediterranean Sea. Cybium 29: 135-140.

Melendez M.J., Baez J.C., Serna-Quintero J.M., et al. 2017. Historical and ecological drivers of the spatial pattern of Chondrichthyes species richness in the Mediterranean Sea. PLoS ONE 12: e0175699. https://doi.org/10.1371/journal.pone.0175699

Moranta J., Massutí E., Stefanescu C., et al. 2008a. Short-term temporal variability in fish community structure at two western Mediterranean slope locations. Deep-Sea Res. Pt. I. 55: 866-880. https://doi.org/10.1016/j.dsr.2008.04.001

Moranta J., Quetglas A., Massutí E., et al. 2008b. Spatio-temporal variations in deep-sea demersal communities off the Balearic Islands (western Mediterranean). J. Mar. Syst. 71: 346-366. https://doi.org/10.1016/j.jmarsys.2007.02.029

Nieto A., Ralph G.M., Comeros-Raynal M.T., et al. 2015. European Red List of marine fishes. Publ. Off. Eur. Union, Luxembourg, $84 \mathrm{pp}$.

Notarbartolo Di Sciara G. 2014. Sperm whales, Physeter macrocephalus, in the Mediterranean Sea: a summary of status, threats, and conservation recommendations. Aquat. Conserv. Mar. Freshw. Ecosyst. 24: 4-10. https://doi.org/10.1002/aqc.2409

Osio G.C., Orio A., Millar C.P. 2015. Assessing the vulnerability of Mediterranean demersal stocks and predicting exploitation status of un-assessed stocks. Fish. Res. 171: 110-121. https://doi.org/10.1016/j.fishres.2015.02.005

Ordines F., Massutí E. Moranta J. et al. 2011. Balearic Islands vs Algeria: two nearby western Mediterranean elasmobranch assemblages with different oceanographic scenarios and fishing histories. Sci. Mar. 75: 707-717.

Peristeraki P., Kypraios N., Lazarakis G., et al. 2008. By-catches and discards of the Greek swordfish fishery. Col. Vol. Sci. Pap. ICCAT 62: 1070-1073.

Polidoro B.A, Livingstone S.R., Carpenter K.E., et al. 2008. Status of the world's marine species. In: Vié J.C., Hilton-Taylor C., Stuart S.N. (eds). Wildlife in a changing world: an analysis of the 2008 IUCN Red List of threatened species. Int. Union Conserv. Nat., Gland, Switzerland, pp. 55-65.

Polidoro B.A., Brooks T., Carpenter K.E., et al. 2012. Patterns of extinction risk and threat for marine vertebrates and habitatforming species in the Tropical Eastern Pacific. Mar. Ecol. Progr. Ser. 448: 93-104 https://doi.org/10.3354/meps09545

QGIS Development Team. 2017. Geographic Information System. Open Source Geospatial Foundation Project. http://www.qgis.org/

R Development Core Team. 2018. R: A language and environment 
for statistical computing. R Foundation for Statistical Computing, Vienna, Austria. https://www.r-project.org/

Ramírez-Amaro S., Ordines F., Terrasa B., et al. 2015. Demersal chondrichthyans in the western Mediterranean: assemblages and biological parameters of their main species. Mar. Freshw. Res. 67: 636-652. https://doi.org/10.1071/MF15093

Relini G., Biagi F., Serena F., et al. 2000. I Selaci pescati con lo strascico nei mari italiani. Biol. Mar. Mediterr. 7: 347- 384.

Rodríguez-Cabello C., González-Pola C., Rodríguez A., et al. 2018. Insights about depth distribution, occurrence and swimming behavior of Hexanchus griseus in the Cantabrian Sea (NE Atlantic). Reg. Stud. Mar. Sci. 23: 60-72. https://doi.org/10.1016/j.rsma.2017.10.015

Russo T., Bitetto I., Carbonara P., et al. 2017. A holistic approach to fishery management: evidence and insights from a Central Mediterranean Case Study (Western Ionian Sea). Front. Mar. Sci. 4: 193 https://doi.org/10.3389/fmars.2017.00193

Sbrana M., Mannini A., Sartor P. et al. 2013. D11 - Report geoReferred information on the spatial and temporal distribution of fishing effort/grounds for the case studies. DG Mare MAREA Mediterranean Halieutic Resources Evaluation and Advice Specific Contract no 7 --STOCKMED: "Stock units: Identification of distinct biological units (stock units) for different fish and shellfish species and among different GFCM-GSAs. 157 pp.

Serena F., Papacostantinou C., Relini G., et al. 2009. Distribution and abundance of spiny dogfish in the Mediterranean sea based on the Mediterranean International Trawl Surveys Program. In: Gallucci V.F., McFarlane G.A., Bargmann G.C. (eds). Biology and management of dogfish sharks. Am. Fish. Soc., Bethesda, Maryland, pp. 139-149.

Sion L., Bozzano A., D’Onghia G., et al. 2004. Chondrichthyes species in deep waters of the Mediterranean Sea. Sci. Mar. 68: 153-162.

https://doi.org/10.3989/scimar.2004.68s3153

Stevens J.D., Bonfil R., Dulvy N., et al. 2000. The effects of fish- ing on sharks, rays, and chimaeras (chondrichthyans), and the implications for marine ecosystems. ICES J. Mar. Sci. 57: 476-494.

https://doi.org/10.1006/jmsc.2000.0724

Stevens J.D., Walker T.I., Cook S.F., et al. 2005. Threats Faced by Chondrichthyan Fish. In: Fowler S.L., Cavanagh R., et al. (eds). Sharks, Rays and Chimaeras: The Status of the Chondrichthyan Fishes. IUCN/SSC Shark Specialist Group, Gland, Switzerland and Cambridge, UK, pp. 48-57.

Tsagarakis K., Mytilineou C., Haralabous J., et al. 2013. Mesoscale spatio-temporal dynamics of demersal assemblages of the Eastern Ionian Sea in relationship with natural and fisheries factors. Aquat. Living Resour. 26: 381-397. https://doi.org/10.1051/alr/2013067

Tserpes G., Tatamanidis G., Peristeraki P. 2006. Oilfish and shark by-catches of the Greek swordfish fishery in the E. Mediterranean; a preliminary analysis applied to "presence-absence" data. Col. Vol. Sci. Pap. ICCAT 59: 987-991.

Tserpes G., Maravelias C.D., Pantazi M., et al. 2013. Distribution of relatively rare demersal elasmobranchs in the eastern Mediterranean. Estuar. Coast. Shelf. Sci. 117: 48-53. https://doi.org/10.1016/j.ecss.2012.09.020

Vasilakopoulos P., Maravelias C.D., Tserpes G. 2014. The Alarming Decline of Mediterranean Fish Stocks. Curr. Biol. 24: $1643-1648$ https://doi.org/10.1016/j.cub.2014.05.070

Wood S.N. 2006. Generalized additive models: an introduction with R. Chapman and Hall/CRC Press. Boca Raton, Florida. 392 pp. https://doi.org/10.1111/j.1541-0420.2007.00905 3.x

Worm B., Davis B., Kettemer L., et al. 2013. Global catches, exploitation rates, and rebuilding options for sharks. Mar. Policy 40: 194-204. https://doi.org/10.1016/j.marpol.2012.12.034

Zuur A.F., Ieno E.N., Elphick C.S. 2010. A protocol for data exploration to avoid common statistical problems. Methods Ecol. Evol. 1: 3-14.

https://doi.org/10.1111/j.2041-210X.2009.00001.x 